\title{
WATER RESOURCES OF THE LAC DU FLAMBEAU INDIAN RESERVATION, WISCONSIN, 1981-86
}

By W.G. Batten and R.A. Lidwin

\section{U.S. GEOLOGICAL SURVEY}

Water-Resources Investigations Report 94-4025

Prepared in cooperation with the

LAC DU FLAMBEAU COMMUNITY

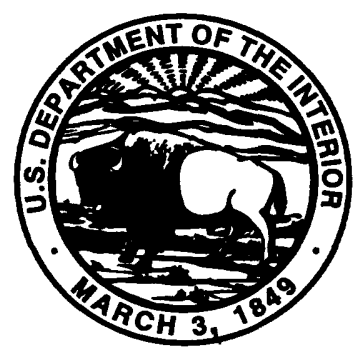

Madison, Wisconsin 


\title{
U.S. DEPARTMENT OF THE INTERIOR BRUCE BABBITT, Secretary
}

\author{
U.S. GEOLOGICAL SURVEY \\ Gordon P. Eaton, Director
}

District Chief

U.S. Geological Survey

6417 Normandy Lane

Madison, WI 53719
U.S. Geological Survey

Branch of Information Services

Box 25286

Denver, CO 80225-0286 


\section{CONTENTS}

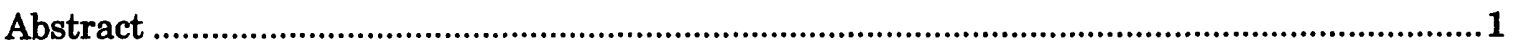

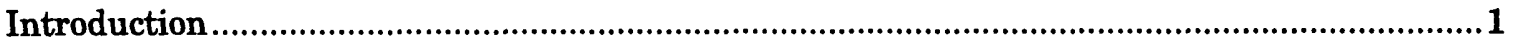

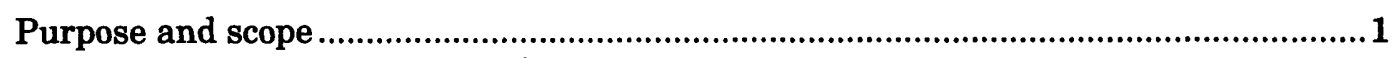

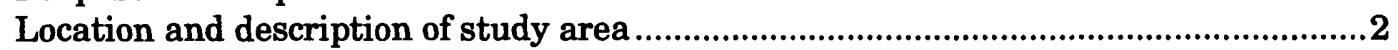

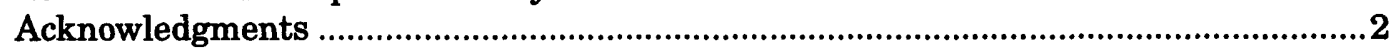

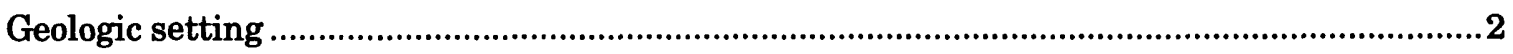

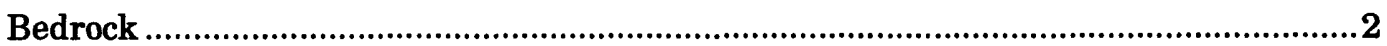

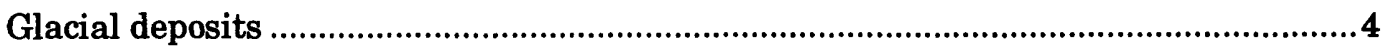

Ground water

Sand and gravel aquifer.......................................................................................

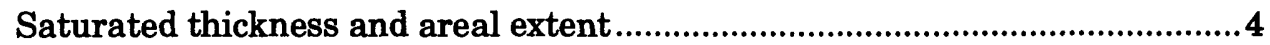

Hydraulic properties ................................................................................... 4

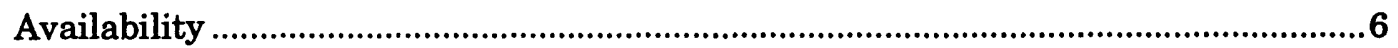

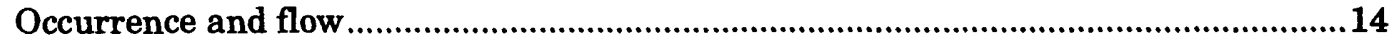

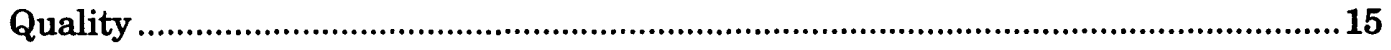

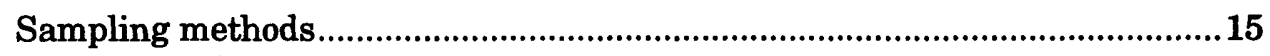

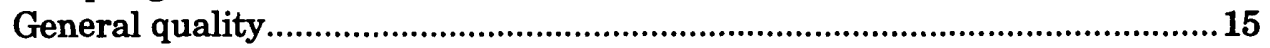

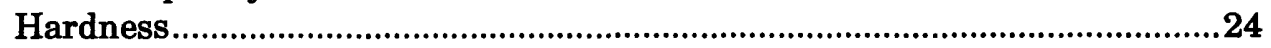

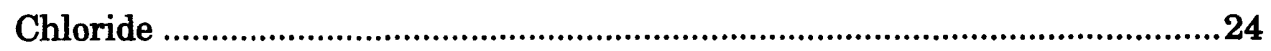

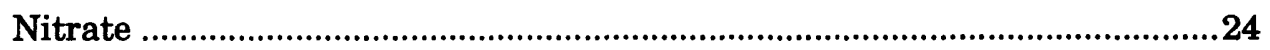

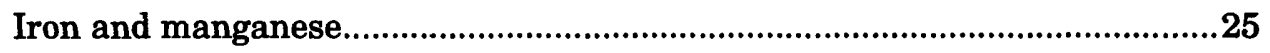

Trace inorganic constituents ....................................................................25

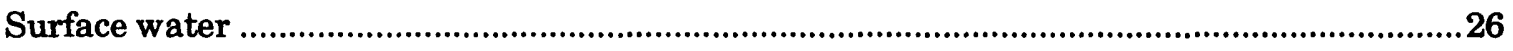

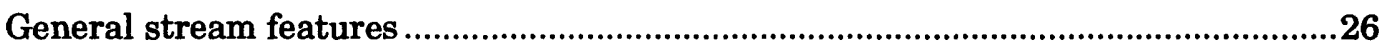

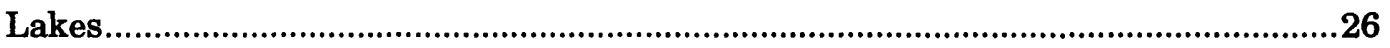

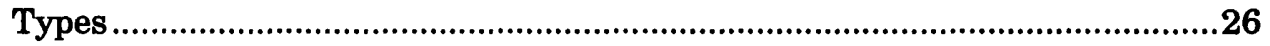

Water quality..........................................................................................26

Sampling methods.................................................................26

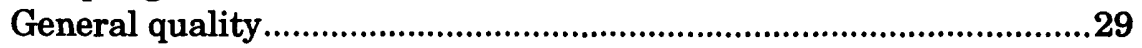

Nutrients and pesticides .....................................................................40

Acid sensitivity ..................................................................................40

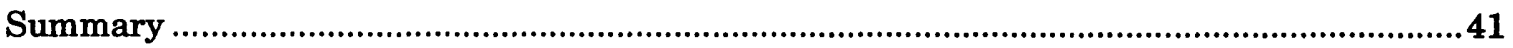

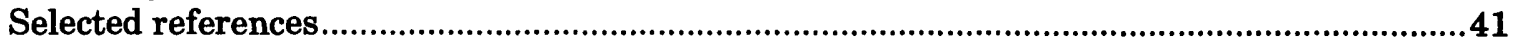




\section{ILLUSTRATIONS}

Plates 1-3. Maps showing:

1. Altitude of Precambrian bedrock surface underlying the Lac du Flambeau Indian Reservation, Wisconsin. In pocket

2. Saturated thickness of glacial deposits underlying the Lac du Flambeau Indian Reservation, Wisconsin. In pocket

3. Altitude of the water table and location of ground-water-quality sampling sites on the Lac du Flambeau Indian Reservation, Wisconsin In pocket

Figure 1. Map showing location of the Lac du Flambeau Indian Reservation, Wisconsin

2. Geologic section through the Lac du Flambeau Indian Reservation, Wisconsin 5

3. Depth profiles of water temperature, dissolved-oxygen concentration, $\mathrm{pH}$, and specific conductance for 22 lakes on the Lac du Flambeau Indian Reservation, Wisconsin 35

\section{TABLES}

Table 1. Physical and hydraulic characteristics of selected wells on the Lac du Flambeau Indian Reservation, Wisconsin

2. Summary of selected chemical analyses of water samples from wells on the Lac du Flambeau Indian Reservation, Wisconsin

3. Chemical analyses of water samples from individual wells on the Lac du Flambeau Indian Reservation, Wisconsin

4. Summary of drinking-water standards for Wisconsin

5. Hydrologic lake types and lake areas, Lac du Flambeau Indian Reservation, Wisconsin

6. Summary of selected chemical analyses of water samples from lakes on the Lac du Flambeau Indian Reservation, Wisconsin

7. Chemical analyses of water samples from selected lakes on the Lac du Flambeau Indian Reservation, Wisconsin 


\title{
CONVERSION FACTORS, VERTICAL DATUM, ABBREVIATED WATER-QUALITY UNITS, AND WELL-NUMBERING SYSTEM
}

$\begin{array}{lcl}\text { Multiply } & \text { By } & \text { To obtain } \\ \text { inch (in.) } & 25.4 & \text { millimeter } \\ \text { foot (ft) } & 0.3048 & \text { meter } \\ \text { mile (mi) } & 1.609 & \text { kilometer } \\ \text { foot per day (ft/d) } & 0.3048 & \text { meter per day } \\ \text { foot squared per day }\left(\mathrm{ft}^{2} / \mathrm{d}\right) & 0.09290 & \text { meter squared per day } \\ \text { gallon (gal) } & 3.785 & \text { liter } \\ \text { million gallons (Mgal) } & 3,785 & \text { cubic meter } \\ \text { million gallons per day (Mgal/d) } & 0.04381 & \text { cubic meter per second } \\ \text { gallon per minute (gal/min) } & 0.06309 & \text { liter per second } \\ \text { acre } & 0.4047 & \text { hectare }\end{array}$

Temperature in degrees Fahrenheit $\left({ }^{\circ} \mathrm{F}\right)$ as follows:

$$
{ }^{\circ} \mathrm{F}=9 / 5\left({ }^{\circ} \mathrm{C}\right)+32
$$

Sea level: In this report, "sea level" refers to the National Geodetic Vertical Datum of 1929-a geodetic datum derived from a general adjustment of the first-order level nets of the United States and Canada, formerly called Sea Level Datum of 1929.

\begin{abstract}
Abbreviated water-quality units used in this report: Chemical concentrations and water temperature are given in metric units. Chemical concentration is given in milligrams per liter $(\mathrm{mg} / \mathrm{L})$ or micrograms per liter $(\mu \mathrm{g} / \mathrm{L})$. Milligrams per liter is a unit expressing the concentration of chemical constituents in solution as weight (milligrams) of solute per volume (liter) of water. One thousand micrograms per liter is equivalent to one milligram per liter. For concentrations less than $7,000 \mathrm{mg} / \mathrm{L}$, the numerical value is the same as for concentrations in parts per million. Specific conductance of water is expressed in microsiemens per centimeter at 25 degrees Celsius $(\mu \mathrm{S} / \mathrm{cm})$. This unit is equivalent to micromhos per centimeter at 25 degrees Celsius $(\mu \mathrm{mho} / \mathrm{cm})$, formerly used by the U.S. Geological Survey.
\end{abstract}

Well-numbering system: Each well used in this report is identified by a local number based on the cadastral-survey system of the U.S. Government. The local number consists of a two-letter abbreviation for the county name followed by the township, range, and section numbers, plus a fourdigit sequence number assigned specifically to the well in a given county. For example, well Vi-40/04E/ 01-0055 is located in Vilas County (Vi), Township 40 north, Range 4 east, section 1, with a sequence number of 55. Only the county abbreviation and sequence number, for example, Vi-55, is used to identify wells in plates 1 and 3 of this report. Well and lake sites are also assigned a unique 15-digit number that is a combination of the site's latitude and longitude plus a two-digit sequence number. This sequence number is used to distinguish between sites that may be less than about $100 \mathrm{ft}$ apart and therefore have the same latitude and longitude. 


\title{
WATER RESOURCES OF THE LAC DU FLAMBEAU INDIAN RESERVATION, WISCONSIN, 1981-86
}

\author{
By W.G. Batten and R.A. Lidwin
}

\section{ABSTRACT}

Unconsolidated glacial sand and gravel deposits provide virtually all water used by residents of the Lac du Flambeau Indian Reservation. Well yields of 10 to 20 gallons per minute can be obtained from these deposits throughout the reservation. Yields of 1,200 gallons per minute are obtained from wells for a fish-rearing facility near the village of Lac du Flambeau. The saturated thickness of glacial deposits ranges from $\mathbf{1 0 0}$ to just less than $\mathbf{2 0 0}$ feet throughout the reservation. Domestic water-supply wells are typically 50 to 150 feet deep.

Estimates of the horizontal hydraulic conductivity of glacial deposits generally range from about 1 to 50 feet per day and average about 20 feet per day. However, a horizontal hydraulic conductivity of about 950 feet per day and a transmissivity of about 71,000 feet squared per day were calculated from aquifer-test data at the fish-rearing facility.

Lakes cover about 20 percent of the reservation. Many of these lakes are small seepage lakes or drainage lakes with surface areas less than 100 acres. Depth profiles of temperature, dissolved oxygen, $\mathrm{pH}$, and specific conductance show that all lakes more than 25 feet deep are thermally stratified during summer months. The median alkalinity and hardness for 34 lake-water samples were 30 and 31 milligrams per liter as calcium carbonate, respectively. The median dissolved-solids concentration was only 50 milligrams per liter. Totalphosphorus concentrations in water samples are high enough to classify some lakes as eutrophic.

Calcium, magnesium, bicarbonate and, to a lesser extent, chloride and sulfate are the major dissolved ions in ground water and surface water. Concentrations of these ions in ground water are twice those in lake water. Nitrate and chloride concentrations in ground-water samples from 25 wells in the reservation were less than the maximum concentrations allowed by Wisconsin drinking-water standards. Iron and, to a lesser extent, manganese seem to be the only constituents present at high enough concentrations to significantly affect drinking-water supplies on the reservation. The maximum concentration of dissolved solids found in ground water on the reservation was 198 milligrams per liter, the median was 86 milligrams per liter. The relatively small amount of dissolved solids in ground water and surface water on the reservation is typical of water quality in northeastern Wisconsin.

\section{INTRODUCTION}

The Lac du Flambeau Indian Reservation is one of six Chippewa reservations in northern Wisconsin whose boundaries were established by treaties signed in 1854 (Lurie, 1987). The Indian population of the Lac du Flambeau Reservation was about 1,400 in 1987 (Wallin, 1988). About 800 non-Indians also had permanent residences within the reservation.

The reservation relies almost exclusively on ground water from shallow glacial sand and gravel deposits for domestic and community water supplies. Numerous lakes within the reservation boundaries provide a productive commercial and recreational fishery for tribal members. These lakes also provide recreation for large numbers of tourists, particularly during the summer months. The protection of the groundwater supply and the lakes is of major interest to tribal leaders and planners concerned with the economic health and welfare of the reservation.

The U.S. Geological Survey (USGS), in cooperation with the reservation community, conducted a hydrologic study of the reservation from 1981 to 1986 . The objectives of the study were to characterize the ground-water hydrology and lake-water quality within the Lac du Flambeau Indian Reservation.

\section{Purpose and Scope}

This report summarizes selected groundwater and lake-water data collected on the Lac 
du Flambeau Indian Reservation from 1981 through 1986. Study objectives frequently changed throughout this 5-year period to meet tribal needs. As a result, this report is not a comprehensive description of water resources of the reservation. The report presents baseline water data for use by tribal planners and others in future site-specific investigations and studies concerned with long-term trends in ground water and lake conditions on the reservation.

Some data have been analyzed and interpreted; other data are presented in table form with little discussion. Data from test holes, seismic-refraction survey lines, and all available wells were used to compile water-table, aquiferthickness, and bedrock-elevation maps. Selected drillers' well-construction data were analyzed to estimate the hydraulic properties of shallow sand and gravel deposits. Water samples from 25 ground-water wells and 21 lakes were analyzed to describe chemical characteristics of water throughout the reservation. The results of these analyses were interpreted and also are presented in tables.

\section{Location and Description of Study Area}

The Lac du Flambeau Indian Reservation is made up of parts of Vilas, Iron, and Oneida Counties (fig. 1) in north-central Wisconsin. It is about $40 \mathrm{mi}$ northwest of Rhinelander, Wis., (fig. 1) and about $10 \mathrm{mi}$ west of the cities of Minocqua and Woodruff.

Reservation boundaries enclose a rectangular area of 81,386 acres (Wallin, 1988). About 70 percent of this area is covered by secondary pine and birch forest (Wallin, 1988). More than 100 lakes, covering about 16,500 acres, are on the reservation. No agricultural crops are grown on the reservation because of poor soil conditions and a short growing season.

\section{Acknowledgments}

The authors thank Mr. Charles A. McCuddy, U.S. Bureau of Indian Affairs, for his help in coordinating project activities.

\section{GEOLOGIC SETTING}

Unconsolidated sediment deposited by glacial ice and glacial-ice meltwater overlies Precambrian crystalline bedrock throughout the area of northern Wisconsin where the Lac du Flambeau Indian Reservation is located.

\section{Bedrock}

The entire Lac du Flambeau Indian Reservation is underlain by rocks originally formed by solidification of melted-rock material (magma) and by volcanic activity from about 1,500 to 2,500 million years ago (Mudrey and others, 1982). These rocks were intermittently remelted and recrystallized (metamorphosed) under extreme heat and pressure during complex and poorly understood regional movement of the Earth's crust. This tectonic activity also caused some fracturing, faulting, and deformation of these rocks.

Precambrian rocks do not crop out at land surface, and very few water wells have been drilled into these rocks on the reservation and in the surrounding area. Therefore, very little is known about the rock types underlying the reservation. These rocks are not differentiated in this report.

The Precambrian rocks are nearly impermeable; that is, their dense crystalline structure does not allow ground water to move through the microscopic spaces between crystals that make up these rocks. The surface of the Precambrian bedrock is therefore treated as an impermeable lower boundary of the overlying glacial deposits in discussions of ground-water flow and occurrence.

Data from drillers' well-construction reports and from 14 seismic-refraction survey lines were plotted and used to compile plate 1, a map showing the altitude of the top of the Precambrian bedrock surface. Altitudes range from $1,388 \mathrm{ft}$ to $1,512 \mathrm{ft}$ above sea level. A broad, shallow valley in which altitudes generally are between about 1,375 and $1,450 \mathrm{ft}$ above sea level runs from north to south through the east-central part of the reservation. The bedrock surface, however, is relatively smooth. This lack of relief on the bedrock surface is the result of more than 1 billion years of stream erosion. Additional 


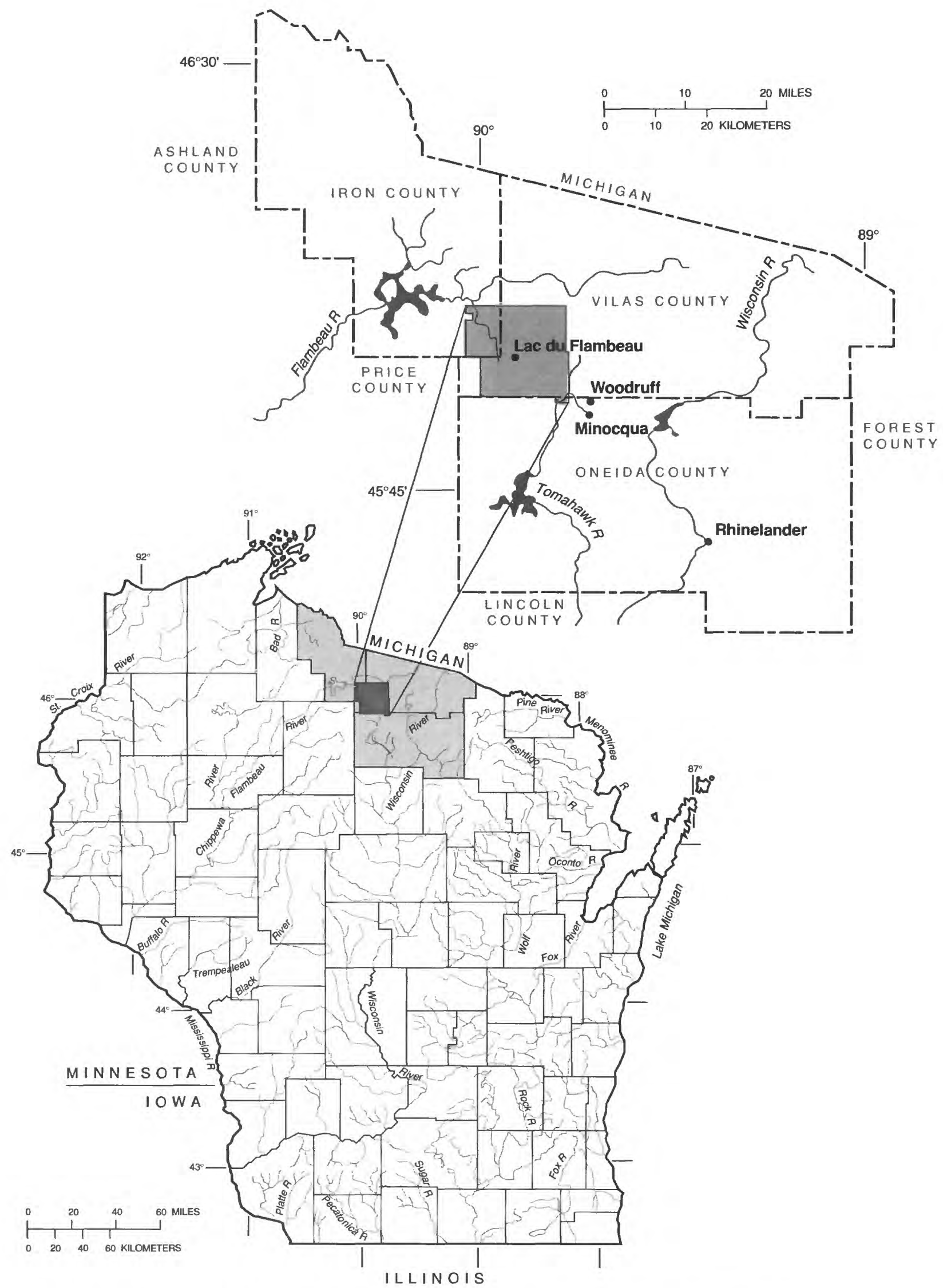

Figure 1. Location of the Lac du Flambeau Indian Reservation, Wisconsin. 
smoothing of the bedrock surface probably resulted as glacial ice sheets advanced into the area during the last 1 to 2 million years.

\section{Glacial Deposits}

Glacial deposits underlying the reservation were laid down directly by glacial ice or by glacial-meltwater streams between about 10,000 and 25,000 years ago (Attig, 1985). The material laid down directly under the base of glacial ice is called till. Material deposited as streambed sediment by streams of meltwater from melting ice is called proglacial fluvial sediment (Attig, 1985). The till, where present, is generally buried beneath about 40 to $60 \mathrm{ft}$ of sandy fluvial sediment on the reservation (Attig, 1985), and it usually overlies varying thicknesses of fluvial sediment as shown in the geologic section in figure 2. The trace of this geologic section is shown on plate 1 . The till is more compacted than the fluvial deposits and is described in well logs as a layer of clay and gravel, clay and sand, or hardpan. This till layer is not mappable throughout the reservation because well-log data are not available for some areas.

The overall thickness of glacial deposits ranges from about $60 \mathrm{ft}$ in the western half to about $240 \mathrm{ft}$ in the east-central part of the reservation. The greatest thickness of deposits is the middle of the Precambrian bedrock valley shown on plate 1 . The overall thickness of glacial deposits is just slightly greater $(10-20 \mathrm{ft})$ than the saturated thickness of glacial deposits shown on plate 2 . Therefore, the overall thickness of glacial deposits at any site can be estimated by adding 10 to $20 \mathrm{ft}$ to the saturated thickness obtained from plate 2 .

All of the glacial deposits have a coarsegrained texture. The streambed (fluvial) material is sand and gravel. The till contains about 70 percent sand-sized particles by weight and siltand clay-sized particles make up the remaining 30 percent (Attig, 1985). Soils of the reservation also are coarse-grained because they have been derived, for the most part, from the weathering of these glacial deposits. Soils in upland areas are generally excessively drained Vilas and Omega sands or sandy loam, or well-drained Pence sandy loam. The wet organic soils are generally moss peat over acidic sedge and woody-peat soils (Hole, 1976).

\section{GROUND WATER}

The Lac du Flambeau Indian Reservation relies entirely on ground water pumped from shallow glacial sand and gravel deposits for water supply. Well-construction data from 56 water-supply wells and 10 small-diameter test wells and results from an aquifer test were used to describe ground-water conditions and the hydraulic properties of glacial deposits in the following sections of the report.

\section{Sand and Gravel Aquifer}

The sand and gravel aquifer consists of saturated glacial sand and gravel that overlie the Precambrian bedrock. The extent, thickness, and hydraulic properties of these deposits affect the occurrence, flow, and availability of ground water.

\section{Saturated Thickness and Areal Extent}

The total saturated thickness of the glacial deposits is considered a single aquifer because the glacial deposits, including the buried till, are generally very sandy and lack fine-grained (siltand clay-sized) material. It should be noted, however, that the buried till, because it is more compacted than the other deposits, may locally impede vertical flow of ground water between the upper and lower fluvial sand and gravel layers shown in figure 2.

The saturated thickness of glacial deposits underlying the reservation is shown on plate 2 . This map was produced by subtracting the altitude of the top of the bedrock (which is the base of the glacial deposits) from the altitude of the water table (which is the top of the saturated zone). The contour lines on plate 2 connect points of equal saturated thickness. The saturated thickness ranges from just less than $60 \mathrm{ft}$ in the northwestern corner of the reservation to more than $220 \mathrm{ft}$ in the east-central part of the reservation. The greatest thickness is in the bedrock valley described earlier and shown on plate 1.

\section{Hydraulic Properties}

Hydraulic properties of the aquifer materials directly determine the amount of ground-water flow and the production capabilities of wells finished in these materials. Two important prop- 


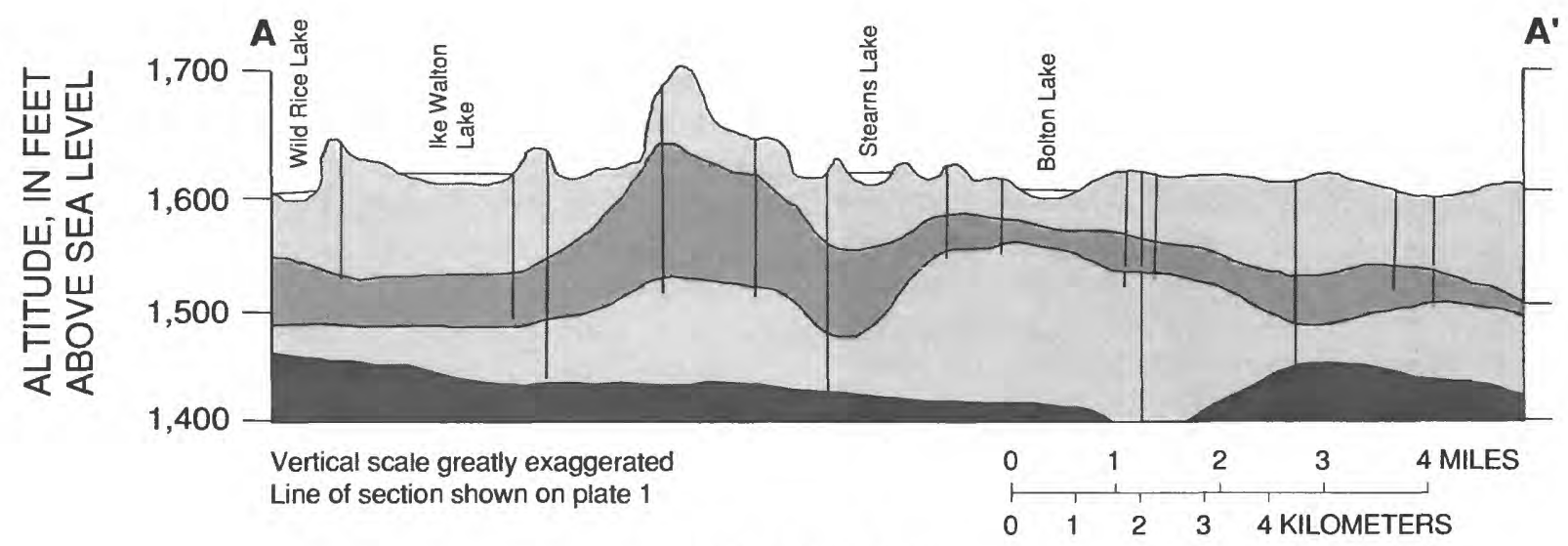

EXPLANATION

Fluvial sand and gravel

Till

Precambrian bedrock

Figure 2. Geologic section through the Lac du Flambeau Indian Reservation, Wisconsin.

erties mentioned in the discussion of rates of ground-water flow are the porosity (n) and the hydraulic conductivity (K) of the glacial materials.

The porosity of the aquifer material is defined as the ratio (or percentage) of the volume of the openings or pore spaces between the individual particles to the total volume of aquifer material. Water moves through these spaces toward a well or to an area, where it discharges to a stream or lake. The porosity of sand and gravel deposits typically ranges from about 20 to 50 percent (Freeze and Cherry, 1979, p. 37). This percentage can vary both areally and with depth because of variations in the mixture of sand, gravel, silt, and clay in the glacial deposits throughout the reservation. A reasonable estimate of porosity for the sandy deposits that make up the sand and gravel aquifer underlying the reservation is about 25 percent (Freeze and Cherry, 1979).

The most important physical property of the sand and gravel aquifer is the horizontal hydraulic conductivity of the deposits that make up this aquifer. The horizontal hydraulic conductivity indicates the relative ability of an aquifer to transmit water. Hydraulic conductivity is defined as the volume of water that will move through a unit area (such as a square foot) of aquifer under a unit hydraulic gradient (such as a foot of hydraulic-head loss per foot of distance) in a unit of time (such as a day). The hydraulic conductivity of an aquifer is commonly expressed as feet per day ( $\mathrm{ft} / \mathrm{d}$ ). Hydraulic conductivity is directly related to the size and arrangement of the pore openings in the aquifer material. Large hydraulic conductivities are associated with sand- or gravel-size deposits that contain only small amounts of silt- or clay-sized particles. These finer-sized particles tend to block pore openings, thus reducing the ability of the aquifer material to transmit water.

Slug-test data, well-construction reports, and the results of a pumped-well aquifer test were analyzed to estimate the horizontal hydraulic conductivity and the transmissivity of the sand and gravel aquifer. These data provide 
a reasonable estimate of the range of the hydraulic conductivity of the aquifer material underlying the reservation.

Slug tests were done in ten 1.5-in.-diameter observation wells installed by the U.S. Geological Survey (observation-well locations shown on pl. 3). According to field analyses of the drill cuttings, all 10 wells were constructed with 3-ft-long slotted screens open to sandy material. Basic well-construction and water-level data for these wells are shown in table 1 . Slug tests were done by instantaneously introducing a known volume of water into each well and measuring the water-level recovery over time. The measurements were then used to calculate the horizontal hydraulic conductivity of the aquifer material immediately surrounding the well according to a method described by Bouwer and Rice (1976). Calculated values for the 10 tests ranged from about 0.7 to $53.5 \mathrm{ft} / \mathrm{d}$. The arithmetic mean was $20.4 \mathrm{ft} / \mathrm{d}$; the median was $19.4 \mathrm{ft} / \mathrm{d}$. These values fall within the broad range of horizontal hydraulic conductivities for silty sand and clean sand (Freeze and Cherry, 1979, p. 29).

The transmissivity of an aquifer is the rate at which water can be transmitted through a unit width of the entire thickness of the aquifer. Transmissivity of an aquifer is calculated by multiplying the saturated thickness of the aquifer material by the hydraulic conductivity of the material. The combination of a large hydraulic conductivity and a large thickness of aquifer material results in an aquifer capable of supplying a large amount of ground water to properly constructed wells. A lack of accurate logs for wells that penetrate the entire thickness of glacial deposits prohibits estimates of the transmissivity of the sand and gravel aquifer throughout the reservation. The presence and thickness of clean sand and gravel deposits (without significant clays and silts) seems to vary even over short distances, as indicated by the well-log data in table 1.

The transmissivity of the sand and gravel aquifer was determined at one site from a pumped-well aquifer test at a well (Vi-958, table 1 and pl. 3) drilled to supply water to a fish-rearing facility in section 6 of Township 40 North, Range 5 East. Water-level declines were measured in several observation wells within $100 \mathrm{ft}$ of the pumped well while discharge from the well was held constant at $1,050 \mathrm{gal} / \mathrm{min}$ for 48 hours. From these data, the transmissivity of the sand and gravel aquifer at this location was calculated to be about $71,000 \mathrm{ft}^{2} / \mathrm{d}$ (feet-squared per day) and the hydraulic conductivity was calculated to be about $950 \mathrm{ft} / \mathrm{d}$. The relatively large hydraulic conductivity is probably due to the very clean sand and gravel deposits underlying the site and the type of well construction. Special well construction included a 12-in.diameter well casing and screen. The screen was $20 \mathrm{ft}$ long, and an 8-in.-thick gravel pack was installed between the screen and the surrounding aquifer material to artificially increase the hydraulic conductivity of the aquifer near the well. Use of the gravel pack resulted in increased well production. Although the hydraulic conductivity determined from this aquifer test is about 40 times higher than the arithmetic mean determined from slug tests in 10 small-diameter observation wells on the reservation, the value of $950 \mathrm{ft} / \mathrm{d}$ still is within the broad range of values for clean sand (Freeze and Cherry, 1979, p. 29).

\section{Availability}

Drilled domestic-supply wells throughout the reservation are typically between 50 and $150 \mathrm{ft}$ deep. Shallow, small-diameter (less than 2 in.) sand-point wells also supply many seasonal and permanent lakefront homes on the reservation. Yields of 10 to $20 \mathrm{gal} / \mathrm{min}$, which are sufficient for domestic purposes, can be obtained throughout the entire reservation. Selected well construction and hydraulic data for 56 water-supply wells and small-diameter test wells are listed in table 1.

A total of 12 community-supply wells screened in sand and gravel provide water to 428 residential and commercial users in the village of Lac du Flambeau and to 4 small developments of less than 25 homes each (Wallin, 1988). These wells pumped a total of about $56 \mathrm{Mgal}$ in 1988 (Wallin, 1988). Several of these wells have pumping capacities of 100 to $200 \mathrm{gal} / \mathrm{min}$. Two large-capacity wells were drilled in 1984 to supply a fish-rearing facility. The facility (not shown) is in section 6 of Township 40 North, Range 5 East, near the village of Lac du Flambeau. These two wells pump a total of about $4 \mathrm{Mgal}$ per day for operation of this facility. 


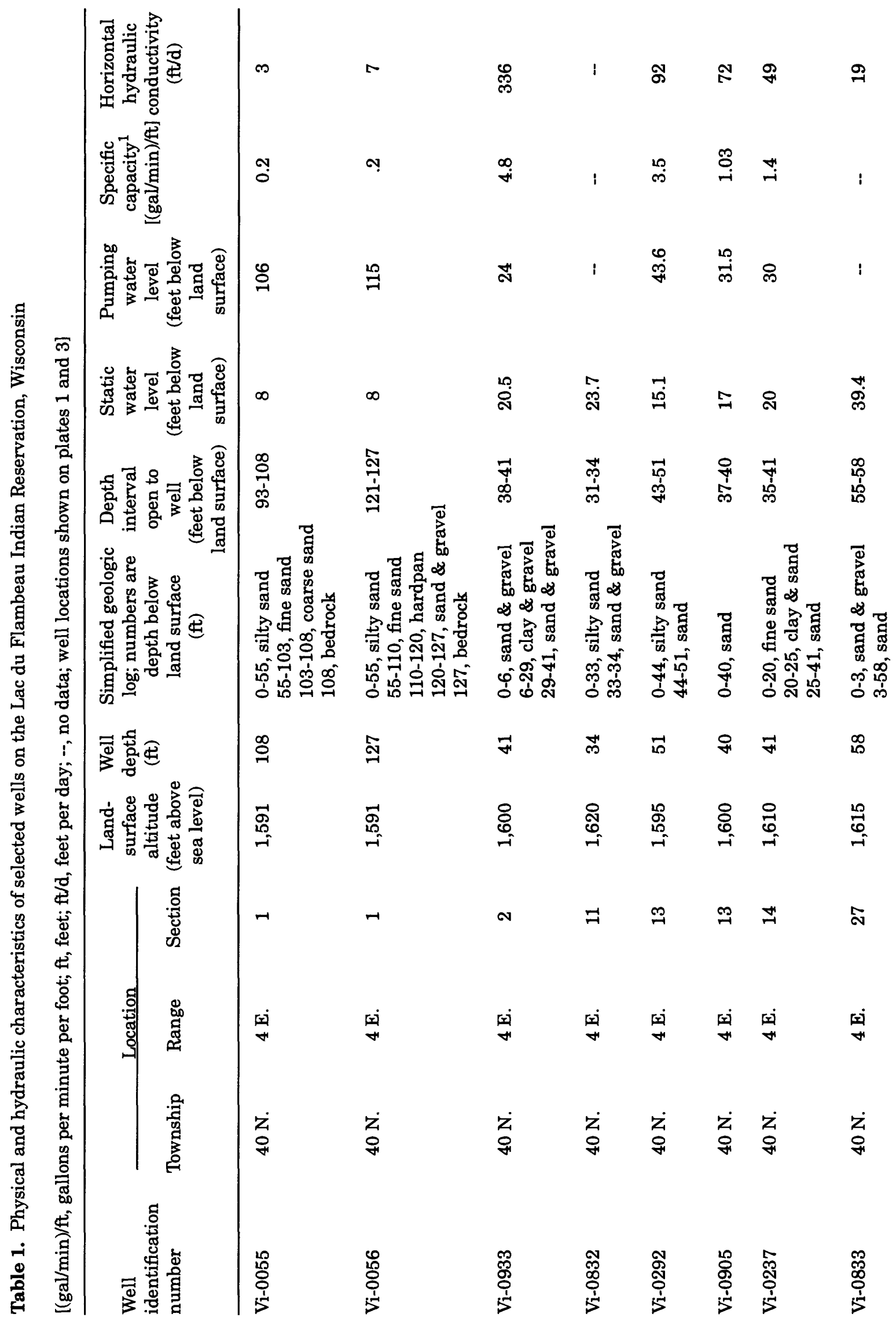




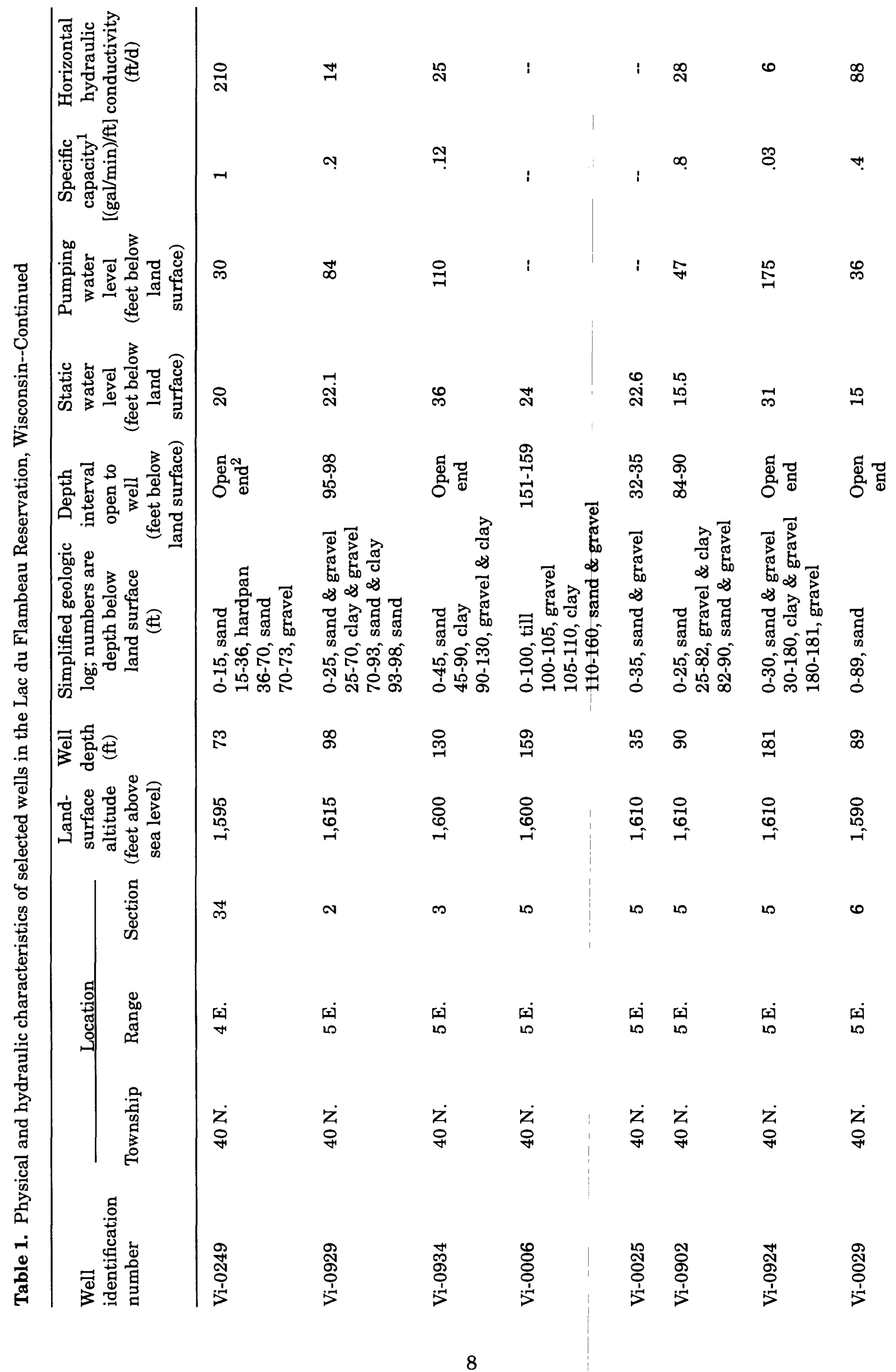




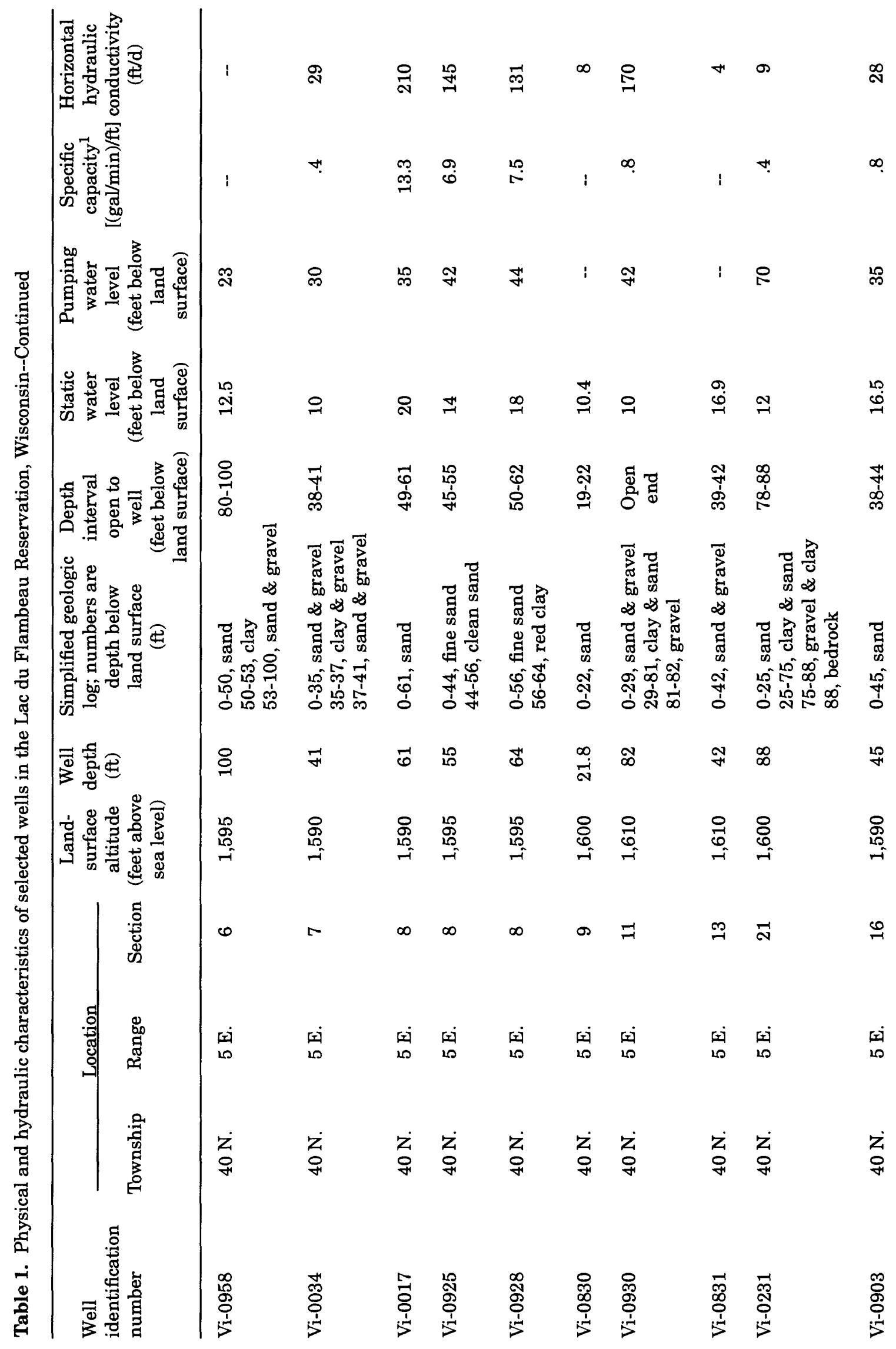




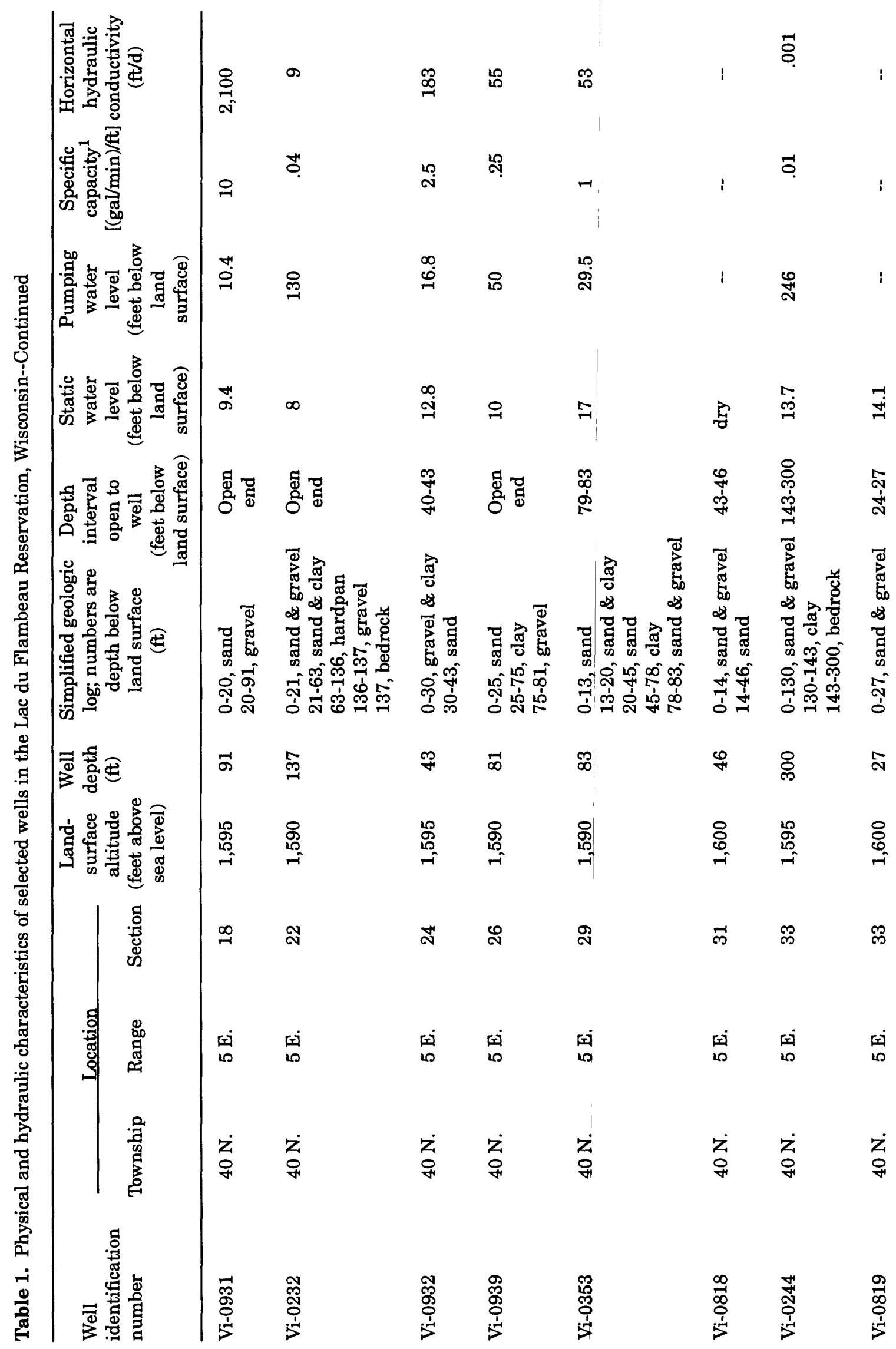




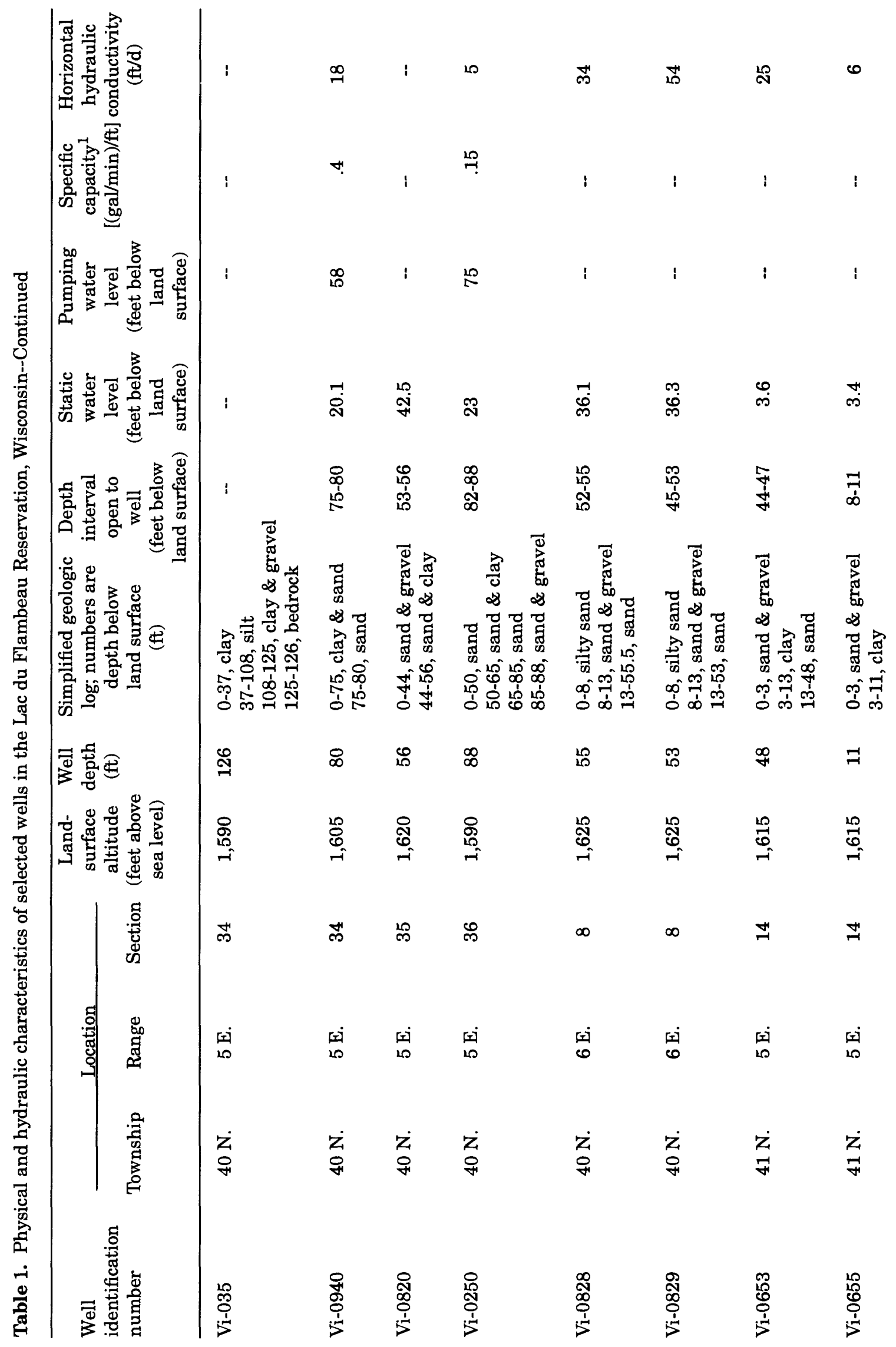




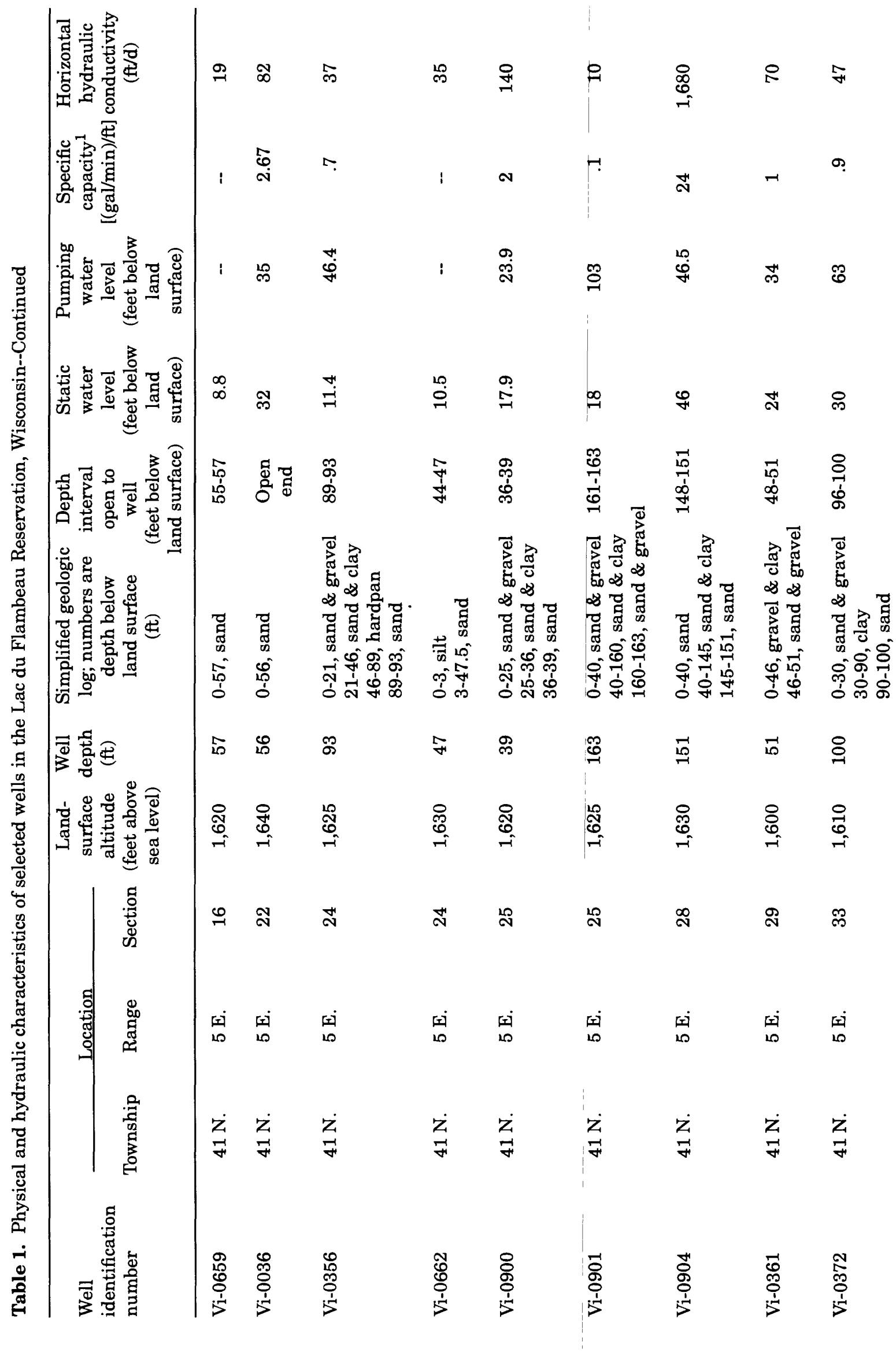




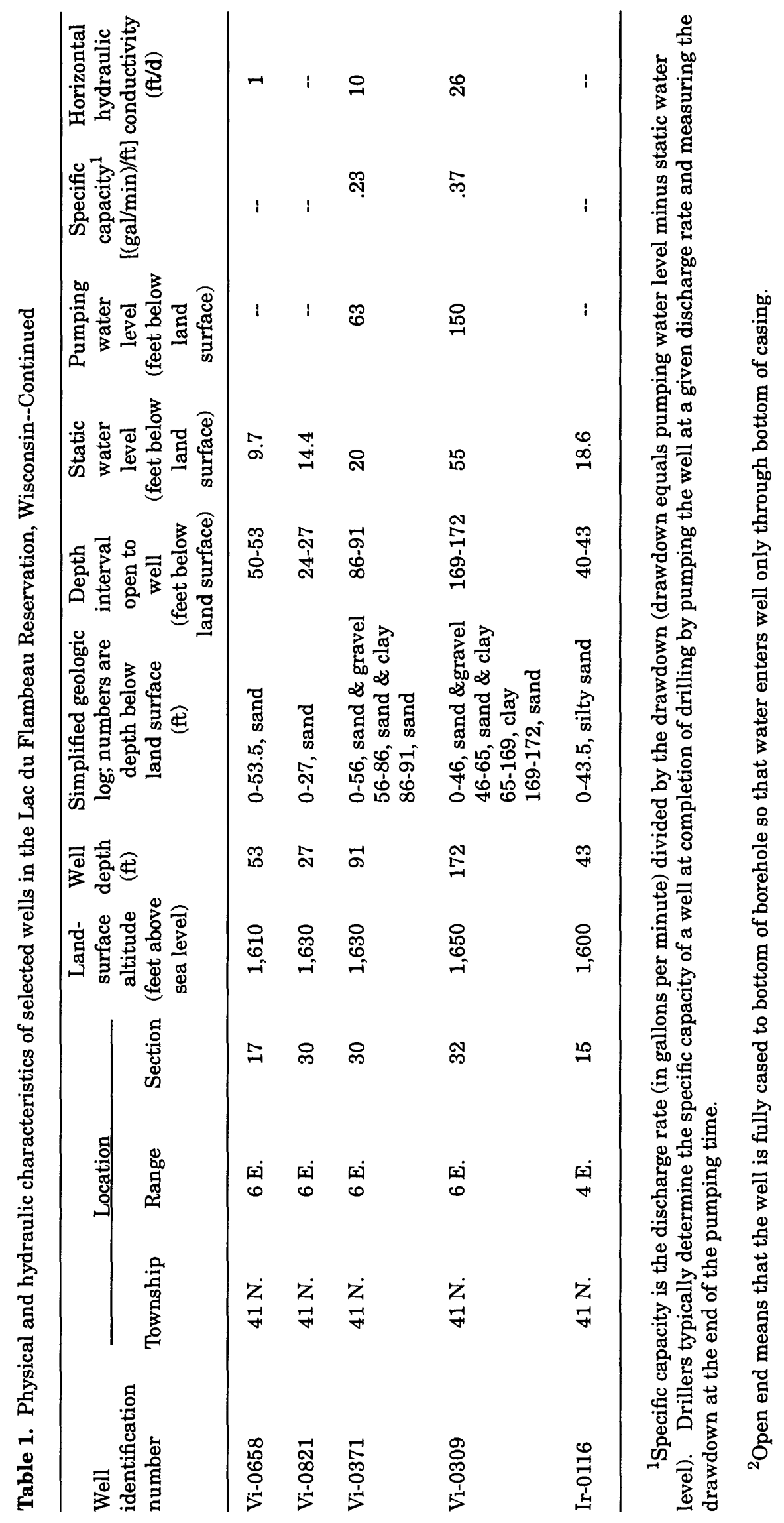




\section{Occurrence and Flow}

Flow of ground water in the Lac du Flambeau Indian Reservation can be best described by a map of the water table (pl. 3). A water-table map is a contour map that depicts the altitude above sea level of the top of the saturated zone where the pressure equals atmospheric pressure. Within the saturated zone, all interconnected openings (pore spaces) in the glacial material or bedrock are filled by water. Contour lines on plate 3 connect points of equal water-table altitude. The map is based on altitudes of reported and measured static water levels in wells and elevations of streams, lakes, and wetlands as given on topographic 7.5-minute quadrangle maps. This water-table map should be considered a general approximation of the water table because most water levels are one-time measurements reported in drillers' construction records spanning a period of many years. Although this map is an approximation, it represents the overall configuration of the water table and can be used to show the general direction of ground-water flow in the sand and gravel aquifer underlying the reservation. The water-table altitude fluctuates seasonally because ground-water levels rise during periods of precipitation and snowmelt or levels decline during extended periods of little or no precipitation. The altitude of the water table ranges from just over $1,630 \mathrm{ft}$ in the northeastern part of the reservation to just under $1,570 \mathrm{ft}$ in areas along the southern edge of the reservation (pl. 3).

The water table is a subdued replica of the land surface of the reservation. The water table has a higher altitude under hills or ridges and is lower but closer to land surface in topographically low areas such as stream valleys, lakes, or wetlands. Lakes, streams, and wetlands are normally in these low areas where the water table intersects the land surface.

Ground water generally flows from high water-table altitudes toward areas of low altitude where it discharges to springs, streams, lakes, or wetlands. Some generalized flow paths (depicted by arrows on plate 3 ) indicate flow at approximately right angles to the water-table contours. Ground water in the Lac du Flambeau area discharges to streams that leave the reservation along the northern and eastern edges or moves along flow paths that leave along the southwestern and southern edges of the reservation.

It can be useful to estimate the rate of movement of the ground water in the aquifer underlying the reservation. For example, if a contaminant is introduced into the aquifer near a community supply well, it becomes important to estimate when the contaminant might reach the well. Although many factors are involved in the movement of contaminants in the ground water, a general idea of the maximum rate of movement of some substances can be obtained by determining the approximate rate of ground-water flow. The rate of ground-water flow can be determined from the following equation.

$$
\mathrm{v}=\left(\frac{\mathrm{K}}{\mathrm{n}}\right)\left(\frac{\mathrm{dh}}{\mathrm{dl}}\right)
$$

where $\mathrm{v}$ is the average velocity of ground water,

$\mathrm{K}$ is the hydraulic conductivity of the aquifer material,

$\frac{d h}{d n}$ is the hydraulic gradient (equivalent $\frac{\mathrm{dh}}{\mathrm{dl}}$ to slope of water-table surface), and $\mathrm{n}$ is the porosity of the aquifer material.

The average rates of flow for the ground water in different areas of the reservation can be calculated with equation 1 . The gradients are relatively flat on the reservation; the difference between the highest water-table altitude and the lowest is only about $60 \mathrm{ft}$. Gradients range from approximately $0.023 \mathrm{ft} / \mathrm{ft}$ to almost zero in wetland areas. An approximate estimate of the average gradient in areas other than wetlands might be slightly less than half of $0.023 \mathrm{ft} / \mathrm{ft}$, or about $0.012 \mathrm{ft} / \mathrm{ft}$. A reasonable hydraulic conductivity $(\mathrm{K})$ value for the sandy materials is about $40 \mathrm{ft} / \mathrm{d}$, with a porosity value of about 25 percent. From these values, the velocity of the ground water would be calculated to be about $1.9 \mathrm{ft} / \mathrm{d}$. This is the horizontal velocity and does not take into consideration any vertical component of flow. This velocity can be increased near pumping wells where the hydraulic gradient is increased locally, thus increasing the rate of ground-water flow. 


\section{Quality}

Ground water was sampled and analyzed to define the general water quality and to determine, by analyzing for indicators of contamination, any general water-quality problems on the reservation. A general water-quality problem, for example, would be an elevated concentration of iron in water, which can cause staining of laundry and plumbing fixtures. Some samples were also analyzed for trace constituents such as cadmium, chromium, lead, mercury, selenium, and arsenic, which are toxic to humans even when they are present in relatively low concentrations, and copper, silver, and zinc. Concentrations of these constituents may indicate rocks containing these minerals beneath the land surface.

\section{Sampling Methods}

Samples were collected from 25 wells screened in the sand and gravel aquifer throughout the reservation. Domestic wells were pumped for about 30 minutes before a sample was collected from a tap as close to the well as possible (usually next to the pressure tank). Samples were collected from small-diameter (2-in.) test wells by first evacuating five casing volumes of water from the well and then collecting the sample with a small-diameter teflon $^{1}$ bailer.

\section{General Quality}

Calcium, magnesium, and bicarbonate are the most abundant common dissolved constituents in ground water underlying the reservation. Sodium, potassium, chloride, and sulfate also are present at lower concentrations. Together, these seven constituents make up almost all dissolved solids in ground water underlying the reservation. Analysis results of common dissolved constituents and selected trace constituents are summarized in table 2 . Complete results of all ground-water analyses for each individual well are listed in table 3. Some chemical constituents shown in table 3 are not discussed in this report but are included in table 3 to provide background data for any future

\footnotetext{
${ }^{1}$ Use of the trade or firm names in this report is for identification only and does not constitute endorsement by the U.S. Geological Survey.
}

studies that may require this type of data. The locations of sampled wells are shown on plate 3 .

The concentration of dissolved solids can be used as a measure of general ground-water quality. The concentration of dissolved solids depends on the chemical composition and solubility of the rock and soil material through which the water moves and the length of time that the water is in contact with these materials. Elevated concentrations of dissolved solids generally do not affect drinking-water quality; however, the Wisconsin Department of Natural Resources (1978) recommends that water with a dissolved-solids concentration greater than 500 $\mathrm{mg} / \mathrm{L}$ not be used for drinking. This recommendation is based on aesthetic (taste) considerations.

Elevated concentrations of several constituents listed in table 2 can cause, or are indicators of, water-quality problems. Elevated concentrations of iron and manganese and hard water are aesthetic concerns but usually are not harmful to health. Elevated chloride concentration is not a serious health problem, but it may indicate more serious ground-water contamination problems. Nitrate, like chloride, is also an indicator of possible contamination; however, unlike chloride, elevated concentrations of nitrate can cause health problems for very young children.

Iron, manganese, chloride, and nitrate, plus fluoride, sulfate, and dissolved solids are included in the list of constituents under Wisconsin's state drinking-water standards (Wisconsin Department of Natural Resources, 1978) shown in table 4. Elevated concentrations of constituents shown in table 4 can limit the use of the water. Primary standards represent minimum standards for protection of health, whereas secondary standards are established for aesthetic reasons that do not affect health.

Elevated concentrations of dissolved solids is not a water-quality problem in the sand and gravel aquifer on the Lac du Flambeau Indian Reservation. The maximum concentration found in 26 samples was $198 \mathrm{mg} / \mathrm{L}$ (table 2). The median concentration was only $86 \mathrm{mg} / \mathrm{L}$. This compares with median concentrations greater than $300 \mathrm{mg} / \mathrm{L}$ in water from aquifers in the southern part of Wisconsin (Kammerer, 1981, p. 
Table 2. Summary of selected chemical analyses of water samplesifrom wells on the Lac du Flambeau Indian Reservation, Wisconsin

[All units are in milligrams per liter unless otherwise indicated; $\mu \$ / \mathrm{cm}$, microsiemens per centimeter; $\mu \mathrm{g} / \mathrm{L}$, micrograms per liter; ${ }^{\circ} \mathrm{C}$, degrees Celsius; <, less than]

\begin{tabular}{|c|c|c|c|c|}
\hline Constituent or characteristic & $\begin{array}{l}\text { Number of } \\
\text { analyses }\end{array}$ & $\begin{array}{l}\text { Minimum } \\
\text { value }\end{array}$ & $\begin{array}{l}\text { Maximum } \\
\text { value }\end{array}$ & $\begin{array}{l}\text { Median } \\
\text { value }\end{array}$ \\
\hline Specific conductance $\left(\mu \mathrm{S} / \mathrm{cm}\right.$ at $\left.25^{\circ} \mathrm{C}\right)$ & 25 & 44 & 450 & 135 \\
\hline pH (standard units) & 25 & 5.7 & 8.6 & 7.1 \\
\hline Temperature $\left({ }^{\circ} \mathrm{C}\right)$ & 25 & 7.5 & 22.5 & 10.0 \\
\hline Hardness as $\mathrm{CaCO}_{3}$ & 26 & 16 & 140 & 56 \\
\hline Calcium, dissolved & 26 & 4.6 & 47 & 16 \\
\hline Magnesium, dissolved & 26 & 1.1 & 7.2 & 4.0 \\
\hline Sodium, dissolved & 26 & 1.4 & 7.3 & 2.1 \\
\hline Potassium, dissolved & 26 & .1 & 5.3 & .8 \\
\hline Alkalinity, total as $\mathrm{CaCO}_{3}$ & 26 & 11 & 148 & 61 \\
\hline Sulfate, dissolved & 26 & 1.0 & 25 & 5.0 \\
\hline Chloride, dissolved & 26 & .2 & 7.1 & 1.1 \\
\hline Fluoride, dissolved & 26 & $<.10$ & 2.1 & .10 \\
\hline Silica, dissolved as $\mathrm{SiO}_{2}$ & 26 & 12 & 40 & 16 \\
\hline Dissolved solids (residue at $180^{\circ} \mathrm{C}$ ) & 26 & 37 & 198 & 86 \\
\hline Nitrate plus nitrite, dissolved as $\mathrm{N}$ & 14 & $<.10$ & .87 & $<.10$ \\
\hline Aluminum, total $(\mu \mathrm{g} / \mathrm{L})$ & 12 & 20 & 100 & 40 \\
\hline Arsenic, total $(\mu \mathrm{g} / \mathrm{L})$ & 12 & 2.0 & 4.0 & 3.0 \\
\hline Barium, dissolved $(\mu \mathrm{g} / \mathrm{L})$ & 12 & 7.0 & 84 & 15.5 \\
\hline Cadmium, total $(\mu \mathrm{g} / \mathrm{L})$ & 12 & $<1.0$ & 14 & 2.0 \\
\hline Chromium, total $(\mu \mathrm{g} / \mathrm{L})$ & 12 & $<1.0$ & 17 & 1.0 \\
\hline Copper, total $(\mu \mathrm{g} / \mathrm{L})$ & 12 & 4.0 & 1,400 & 110 \\
\hline Iron, dissolved $(\mu \mathrm{g} / \mathrm{L})$ & 26 & 3.0 & 43,000 & 40 \\
\hline Iron, total $(\mu \mathrm{g} / \mathrm{L})$ & 12 & 60 & 18,000 & 150 \\
\hline Lead, total $(\mu \mathrm{g} / \mathrm{L})$ & 12 & $<1$ & 15 & 5 \\
\hline Manganese, dissolved $(\mu \mathrm{g} / \mathrm{L})$ & 24 & $<1$ & 3,800 & 42 \\
\hline Manganese, total $(\mu \mathrm{g} / \mathrm{L})$ & 12 & 10 & 370 & 20 \\
\hline Mercury, total $(\mu \mathrm{g} / \mathrm{L})$ & 12 & $<.10$ & .20 & $<.10$ \\
\hline Selenium, total $(\mu \mathrm{g} / \mathrm{L})$ & 12 & $<1$ & 1 & $<1$ \\
\hline Zinc, total $(\mu \mathrm{g} / \mathrm{L})$ & 12 & 50 & 4,200 & 140 \\
\hline
\end{tabular}




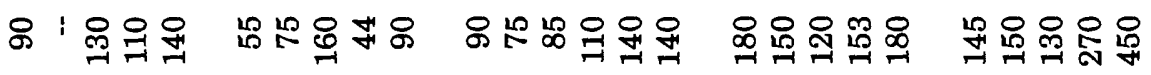

$88888 \quad 88888 \quad 888888 \quad 88888 \quad 80888$

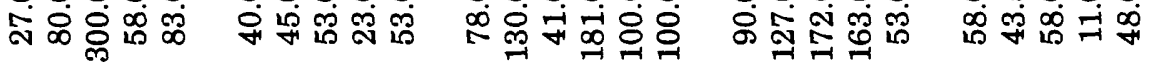

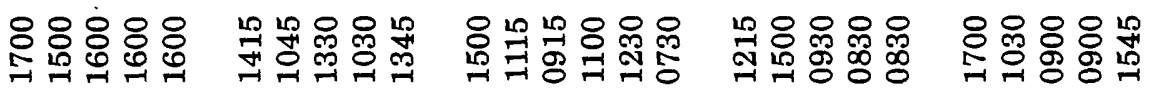

య ஜ

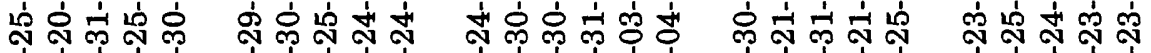
க்

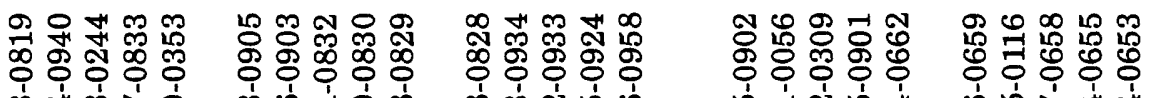
计施

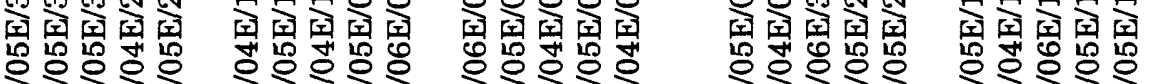

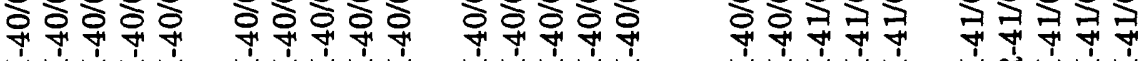

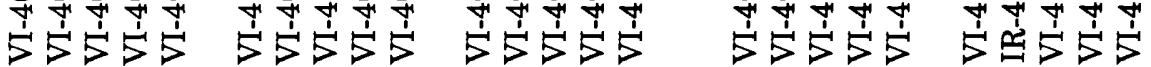




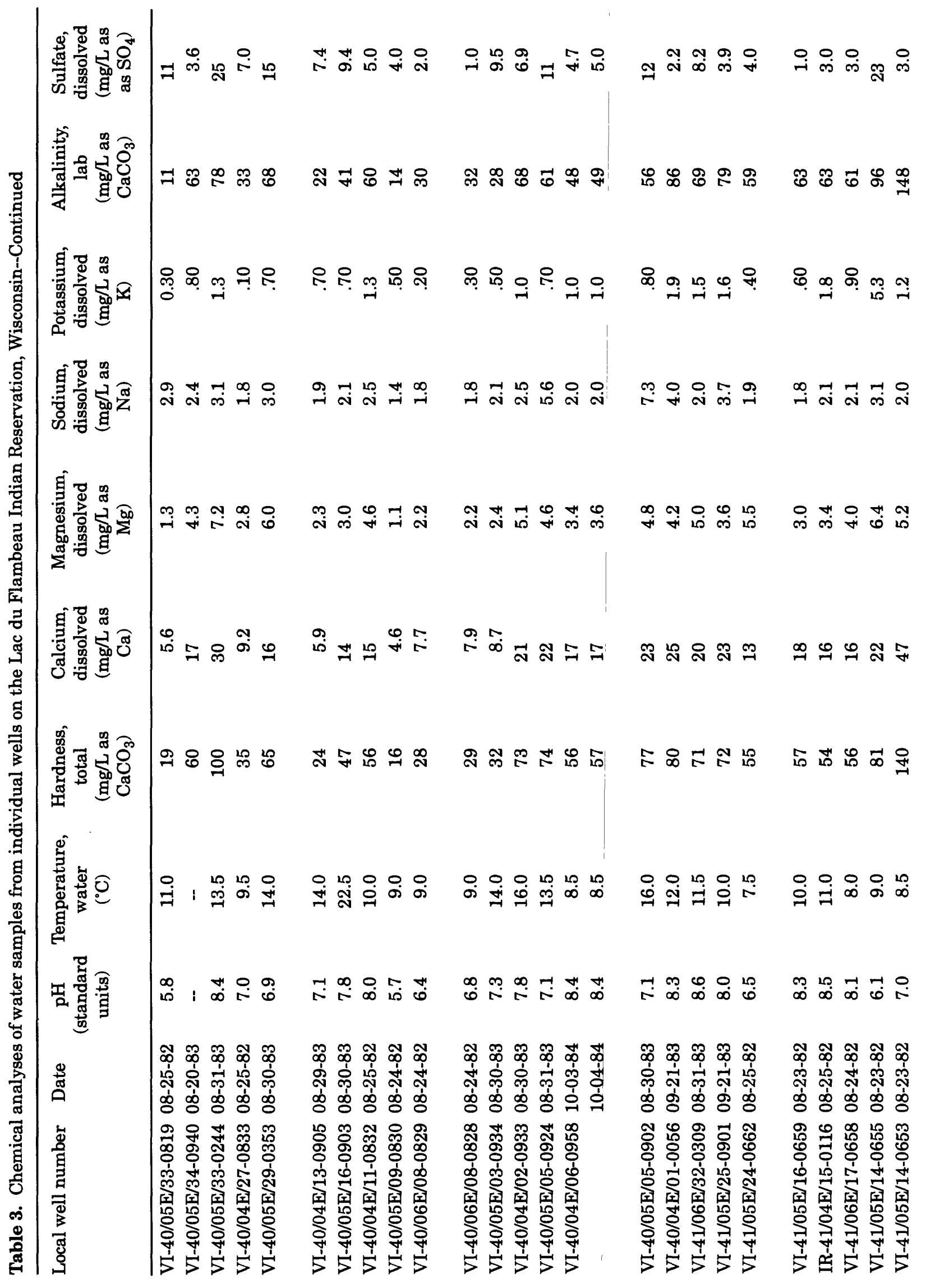




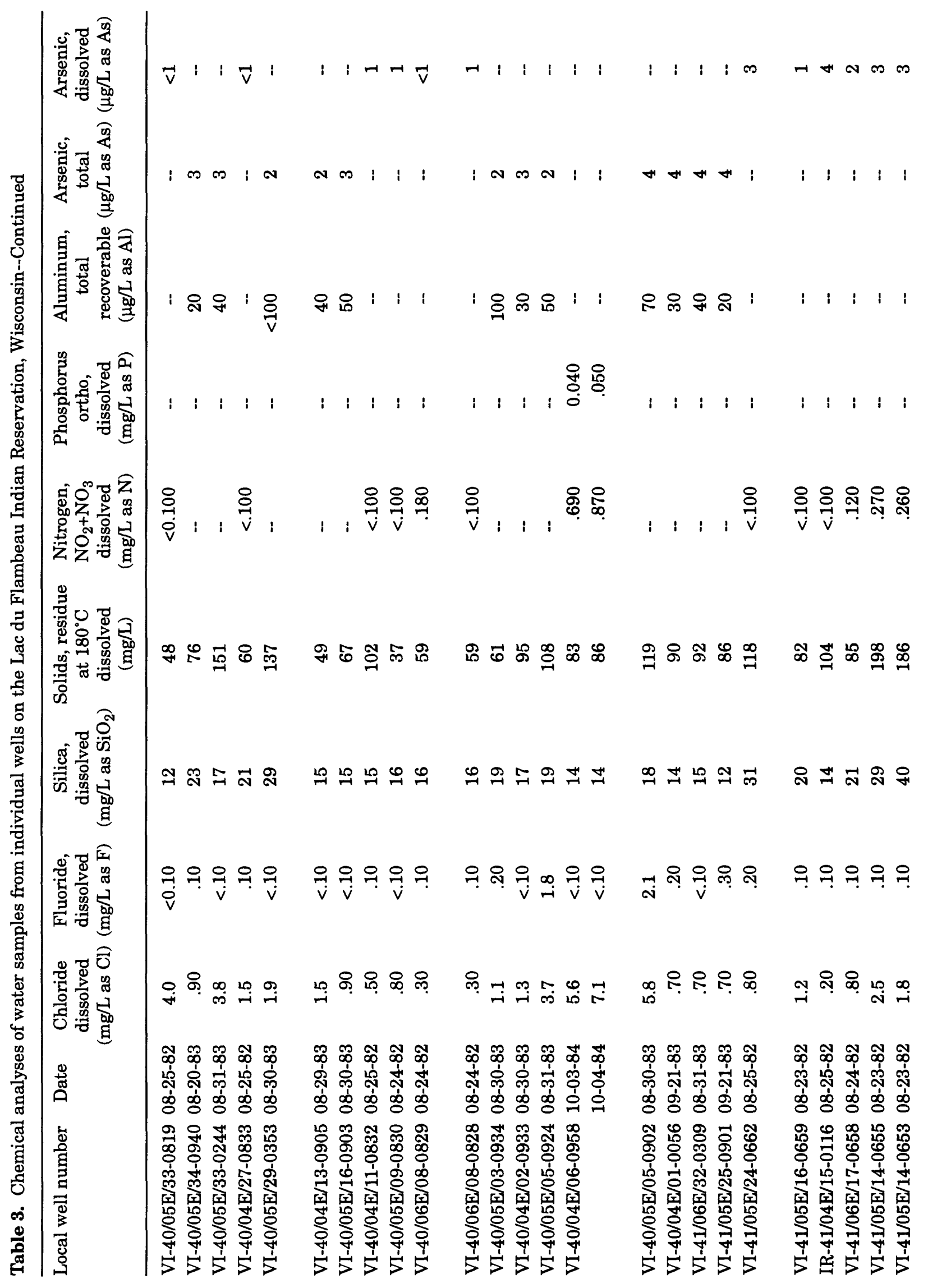




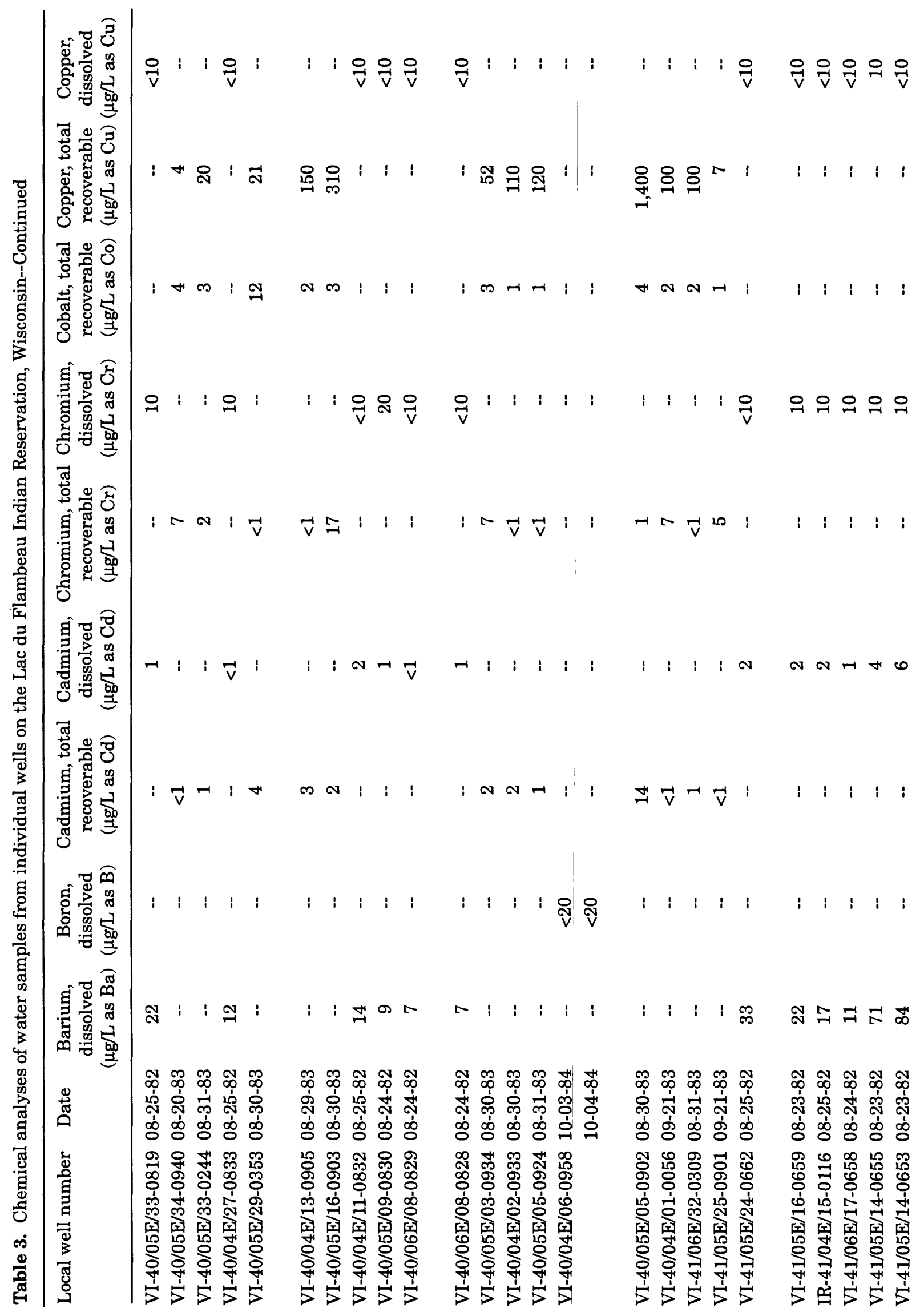




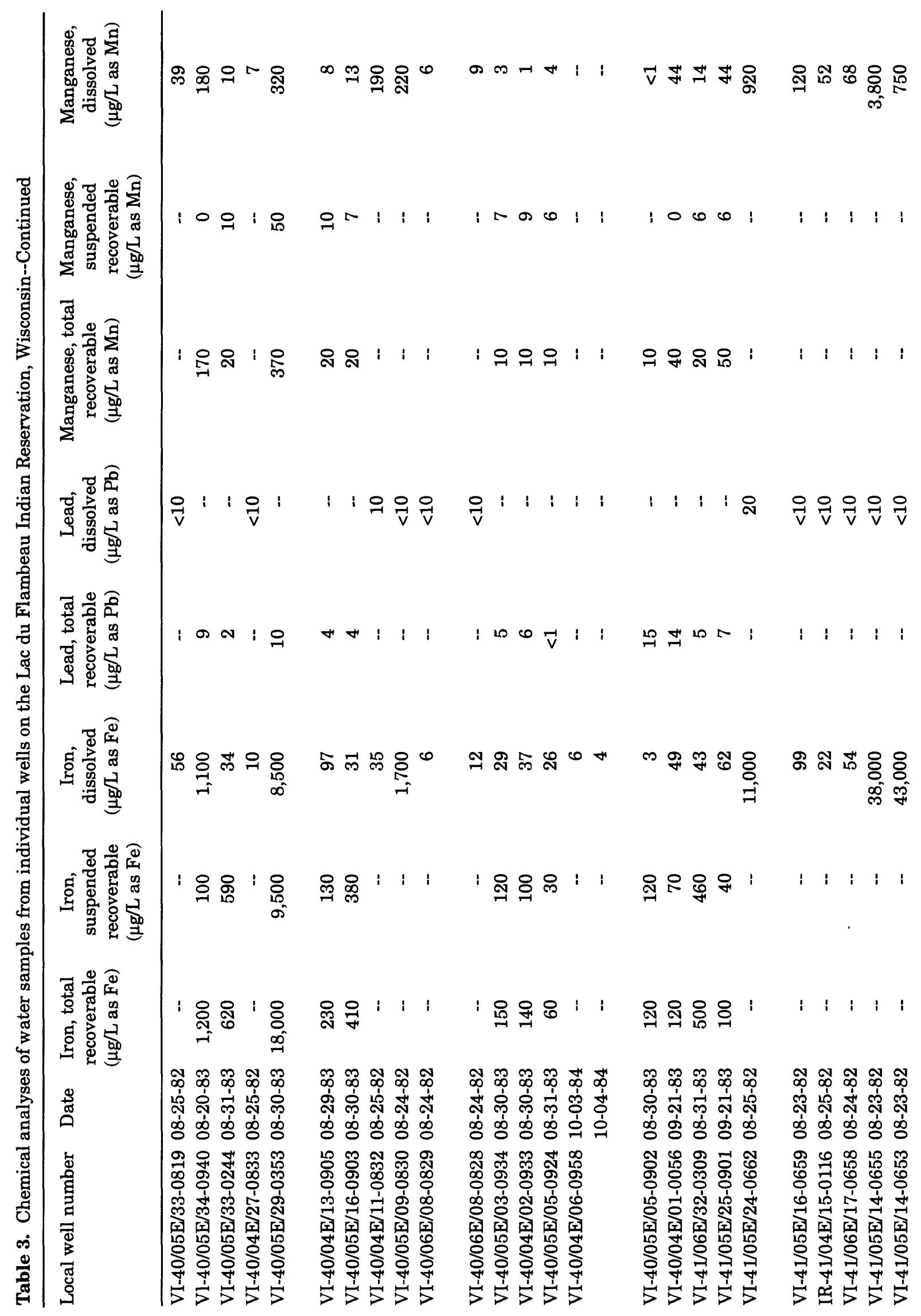




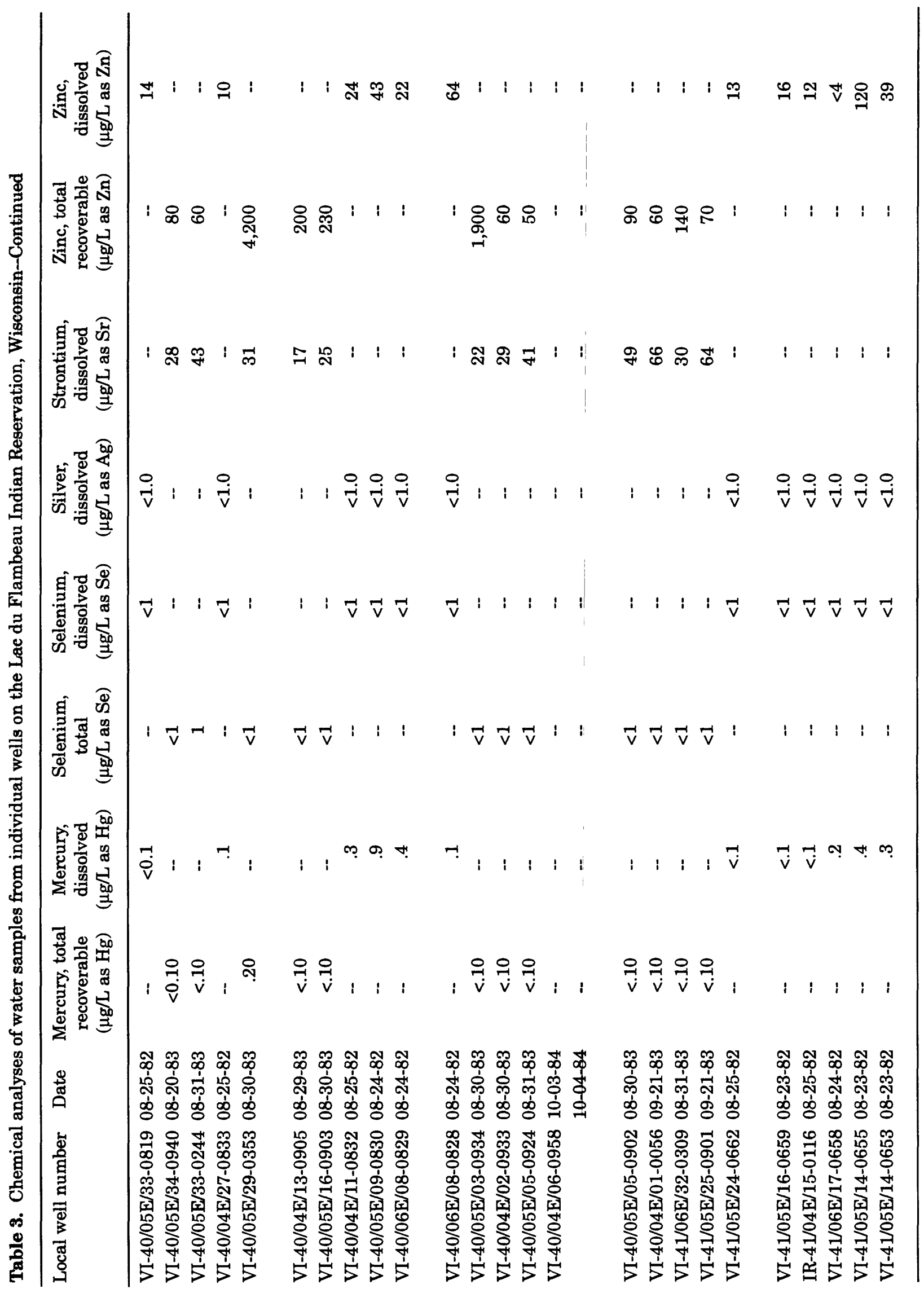


Table 4. Summary of drinking-water standards for Wisconsin

[From Wisconsin Department of Natural Resources, 1978; --, standard not applicable; (all concentrations in milligrams per liter and micrograms per liter (printed in parentheses) unless otherwise indicated)]

Maximum recommended concentration

Constituent

Primary (health) standard Secondary (aesthetic) standard

\begin{tabular}{|c|c|c|c|c|}
\hline \multicolumn{5}{|c|}{ Inorganic chemicals } \\
\hline Arsenic & 0.05 & $(50)$ & - & - \\
\hline Barium & 1 & $(1,000)$ & -- & - \\
\hline Cadmium & .01 & (10) & - & - \\
\hline Chromium & .05 & $(50)$ & - & $\cdots$ \\
\hline Fluoride & 2.2 & -- & - & $\cdots$ \\
\hline Lead & .05 & $(50)$ & - & -- \\
\hline Mercury & .002 & $(2)$ & -- & -- \\
\hline Nitrate (as N) & 10 & -. & - & -- \\
\hline Selenium & .01 & (10) & - & - \\
\hline Silver & .05 & $(50)$ & - & - \\
\hline Chloride & -- & - & 250 & - \\
\hline Color & -. & - & 15 units & - \\
\hline Foaming agents (MBAS) & - & -- & .5 & -- \\
\hline Hydrogen sulfide & -. & -- & \multicolumn{2}{|c|}{ Not detectable } \\
\hline Iron & -- & -- & .3 & $(300)$ \\
\hline Manganese & - & - & .05 & $(50)$ \\
\hline Odor & -- & -- & 3 & Threshold number \\
\hline Sulfate & -. & -. & 250 & - \\
\hline Total residue & -- & - & 500 & - \\
\hline Zinc & -- & - & 5 & $(5,000)$ \\
\hline \multicolumn{5}{|c|}{ Organic chemicals } \\
\hline \multicolumn{5}{|l|}{ Chlorinated hydrocarbons } \\
\hline Endrin & .0002 & $(.2)$ & -- & -- \\
\hline Lindane & .004 & (4) & -- & -. \\
\hline Methoxychlor & .1 & $(100)$ & $\cdots$ & - \\
\hline Toxaphene & .005 & (5) & -- & -- \\
\hline \multicolumn{5}{|l|}{ Chlorophenoxy herbicides } \\
\hline $2,4-D$ & .1 & $(100)$ & - & -. \\
\hline 2, 4, 5-TP (Silvex) & .01 & (10) & $-\cdots$ & -- \\
\hline
\end{tabular}


10). The low concentration of dissolved solids in the ground water results from the relative insolubility of the rock and soil material in the area. For this reason, any well-water sample on the reservation that does have an elevated dissolved-solids concentration (for example, greater than $500 \mathrm{mg} / \mathrm{L}$ ) may indicate a possible contamination problem. Ground water underlying the reservation, as much of northern Wisconsin (where glacial deposits lie directly over Precambrian rocks), has low alkalinity. Alkalinity is a measure of the ability of water to neutralize acid. On the Lac du Flambeau Indian Reservation, alkalinity basically is a measure of the concentration of dissolved bicarbonate ions (from carbonate minerals) in the ground water. Although bicarbonate is one of the major ions found in ground water on the reservation, alkalinities are somewhat low because carbonate minerals are scarce in the glacial and bedrock materials beneath the reservation. Median alkalinity concentrations for water from aquifers in Wisconsin range from about 160 to $260 \mathrm{mg} / \mathrm{L}$ (Kammerer, 1981, p. 14). This compares with the median alkalinity of $61 \mathrm{mg} / \mathrm{L}$ and a maximum value of $148 \mathrm{mg} / \mathrm{L}$ for ground-water samples from the Lac du Flambeau Indian Reservation. Three samples had alkalinities less than $25 \mathrm{mg} / \mathrm{L}$. In some cases, water with alkalinity below $25 \mathrm{mg} / \mathrm{L}$, low $\mathrm{pH}$, and low hardness may become corrosive when chlorinated because of its inability to neutralize acid (Kammerer, 1981, p. 14).

\section{Hardness}

Hardness is caused by the presence of calcium and magnesium in water. Iron, manganese, aluminum, and a few other metals can also contribute to hardness if present in high enough concentrations. Hard water typically forms hard scales and other insoluble residues that build up in plumbing and can cause deterioration of plumbing and appliances.

The U.S. Geological Survey uses the following classification scheme to evaluate and compare hardness of water from different sources (Durfor and Becker, 1964, p. 27). This classification is:

\begin{tabular}{cc}
$\begin{array}{l}\text { Hardness } \mid \text { range } \\
\left(\mathrm{mg} / \mathrm{L} \text { as } \mathrm{CaCO}_{3}\right)\end{array}$ & Hardness description \\
\hline $0-60$ & Soft \\
$61-120$ & Moderately hard \\
$121-180$ & Hard \\
Greater than 180 & Very hard
\end{tabular}

The hardness of ground water from the sand and gravel aquifer underlying the reservation ranged from 16 to $140 \mathrm{mg} / \mathrm{L}$ with a median of $56 \mathrm{mg} / \mathrm{L}$ (table 2). Water from 15 of 25 sampled wells had hardness concentrations of $60 \mathrm{mg} / \mathrm{L}$ or less, thus classifying as soft. One sample, with a hardness of $140 \mathrm{mg} / \mathrm{L}$, is classified hard. (Samples from the remaining nine wells are classified as moderately hard).

\section{Chloride}

The concentration of chloride in rocks and soil generally is low (Hem, 1985, p. 118). The Wisconsin Department of Natural Resources (1978) recommends that water with a chloride concentration greater than $250 \mathrm{mg} / \mathrm{L}$ not be used for drinking (table 4).

Chloride concentrations in ground water on the reservation also are low. Concentrations ranged from $0.2 \mathrm{mg} / \mathrm{L}$ to a high of only $7.1 \mathrm{mg} / \mathrm{L}$ in 26 samples (tables 2 and 3). These concentrations can be compared with Kammerer's findings (1981) that chloride concentrations exceeded 18 $\mathrm{mg} / \mathrm{L}$ in only 10 percent of 819 samples from wells screened in sand and gravel throughout the State. Chloride concentrations greater than 50 $\mathrm{mg} / \mathrm{L}$ in ground water on the reservation would probably indicate ground-water contamination from road salt or human or animal waste. This concentration, though somewhat arbitrary, is significantly higher than the median concentration $(1.1 \mathrm{mg} / \mathrm{L})$ of the 25 samples collected on the reservation.

\section{Nitrate}

Various activities can increase nitrate concentrations in ground water. Nitrate can be introduced into the soil naturally from plant decay; however, elevated nitrate concentrations generally are caused by contamination from animal-waste disposal, septic systems, and from nitrogen fertilizer applied to agricultural fields. Rural areas and unsewered residential areas are 
therefore most likely to have elevated concentrations of nitrate in ground water.

The drinking-water standard for the State of Wisconsin for nitrate is $10 \mathrm{mg} / \mathrm{L}$ as nitrogen (table 4). Like chloride, elevated concentrations of nitrate may indicate other contaminants from such sources as septic systems and barnyards or other animal-waste disposal sites.

Like chloride, no elevated nitrate concentrations were found in any of the 14 samples collected on the reservation (tables 2 and 3 ). Concentrations ranged from less than the laboratory detection limit of $0.1 \mathrm{mg} / \mathrm{L}$ to $0.87 \mathrm{mg} / \mathrm{L}$. Although none of the 14 samples had an elevated nitrate concentration, nitrate contamination could still become a problem in the Lac du Flambeau area where wells are typically screened in shallow sand and gravel deposits. In addition, the depth to the water table is relatively shallow, and septic-system leachate could reach the water table quickly if a septic system should fail.

\section{Iron and Manganese}

Elevated concentrations of iron and manganese in ground water impart an objectionable taste to the water and cause staining of laundry and plumbing fixtures. Elevated iron and manganese concentrations pose no known health hazard. The Wisconsin Department of Natural Resources (1978), however, recommends maximum concentrations of $300 \mu \mathrm{g} / \mathrm{L}(0.3 \mathrm{mg} / \mathrm{L})$ for iron and $50 \mu \mathrm{g} / \mathrm{L}$ for manganese (table 4).

Iron concentrations in the 26 samples fall into two groups. Twenty samples had dissolvediron concentrations of less than $100 \mu \mathrm{g} / \mathrm{L}$, and the remaining 6 samples had concentrations ranging from 1,100 to $43,000 \mu \mathrm{g} / \mathrm{L}$ (table 3). Dissolvedmanganese concentrations also covered a wide range, from less than $1 \mu \mathrm{g} / \mathrm{L}$ to $3,800 \mu \mathrm{g} / \mathrm{L}$ (tables 2 and 3) with a median of $42 \mu \mathrm{g} / \mathrm{L}$. Kammerer (1981) also found that wide ranges of iron and manganese concentrations are present in all aquifers in Wisconsin. His statewide summary shows that concentrations of both iron and manganese exceed the drinking-water standards in water from more than 25 percent of all wells from all aquifers in the State.

Elevated concentrations of iron and manganese are found in Wisconsin rocks and soils. The amount of iron and manganese in ground water is affected by complex chemical and biological processes. Because of this, iron and manganese concentrations can differ considerably at the local level and are difficult to explain or predict.

\section{Trace Inorganic Constituents}

Water samples from 12 of the 25 wells were analyzed for several constituents that are rare in rock and soil materials. These constituents are commonly referred to as "trace metals" or "trace inorganics." Metals included in this group are cadmium, chromium, copper, lead, mercury, barium, silver, and zinc; nonmetals include arsenic, boron, and selenium. Many of these are of particular concern because they are toxic to humans even in low concentrations in drinking water. For each of the following trace constituents, a drinking-water regulation has been established by the U.S. Environmental Protection Agency (1986):

$\begin{array}{lrlr}\text { Arsenic } & 50 \mu \mathrm{g} / \mathrm{L} & \text { Barium } & 1,000 \mu \mathrm{g} / \mathrm{L} \\ \text { Cadmium } & 10 \mu \mathrm{g} / \mathrm{L} & \text { Chromium } & 50 \mu \mathrm{g} / \mathrm{L} \\ \text { Lead } & 50 \mu \mathrm{g} / \mathrm{L} & \text { Mercury } & 2 \mu \mathrm{g} / \mathrm{L} \\ \text { Selenium } & 10 \mu \mathrm{g} / \mathrm{L} & \text { Silver } & 50 \mu \mathrm{g} / \mathrm{L}\end{array}$

Recommended maximum permissible concentrations for copper and zinc of 1,000 and $5,000 \mu \mathrm{g} / \mathrm{L}$, respectively, are given in the Wisconsin drinking-water standards. These limits are based on taste considerations. The recommended limit for boron is $750 \mu \mathrm{g} / \mathrm{L}$ (National Academy of Sciences, National Academy of Engineering, 1973). Elevated concentrations of several of these metals are often not the result of their presence in the aquifer. The sources of copper, lead, zinc, and cadmium in drinking water commonly are pumps, pressure tanks, and plumbing that make up the distribution system.

Cadmium was the only trace constituent that exceeded the Wisconsin drinking-water standard $(10 \mu \mathrm{g} / \mathrm{L})$ in water samples from wells on the reservation (tables 2 and 3). The concentration in one sample was $14 \mu \mathrm{g} / \mathrm{L}$. This sample was collected from an observation well not used as a source of drinking water. 


\section{SURFACE WATER}

Lakes and wetlands are a major natural resource of the Lac du Flambeau Indian Reservation. The lake fisheries are an important part of the woodland culture and economy of the reservation residents. Large wetland areas provide habitat for birds and wildlife also important to the culture. Only a few streams flow within the reservation boundaries and are not an integral part of the reservation culture and economy.

Lakes on the reservation have been classified according to hydrologic type and water samples have been collected from selected lakes to determine present water quality. Streamflow and stream-water-quality data have not been collected as part of this study.

\section{General Stream Features}

Three rivers drain the Lac du Flambeau Indian Reservation. The Bear River (pl. 3) flows northwestward out of Flambeau Lake and drains much of the central and northwestern parts of the reservation to the Flambeau River (fig. 1). Drainage in the northeastern part of the reservation is into the Trout River (pl. 3), which also flows northward to the Flambeau River. The Tomahawk River (pl. 3) drains the extreme southeastern corner of the reservation and flows southward to the Wisconsin River (fig. 1). All of these streams flow toward and ultimately drain into the Mississippi River (not shown).

\section{Lakes}

All or part of 126 lakes are within the Lac du Flambeau Indian Reservation. As in much of northern Wisconsin, many of these lakes result from water filling depressions, large and small, that were created by land-forming processes during the last period of glaciation. Irregular shorelines surrounded by a mixture of northern hardwood and conifer forests provide scenic backgrounds for commercial and recreational fishing and tourism, all of which are important sources of income for many residents. Maintaining the water quality of these lakes is a priority for tribal leaders.

\section{Types}

The lakes on the reservation can be classified as one of three hydrologic types for discussion purposes. Drainage lakes are those that have at least one stream flowing in and at least one stream flowing out. Lakes with an outlet stream only are classified as spring lakes. Lakes with no inlets or outlets are classified as seepage lakes. Lakes of all three classifications are present on the Lac du Flambeau Indian Reservation. Major lakes, wholly or partly within the reservation boundaries, are listed in table 5 by hydrologic type.

Drainage lakes generally receive a high percentage of water from inflowing streams and a relatively minor amount from ground-water inflow. Direct precipitation generally is a minor source of water to these lakes. Spring lakes and seepage lakes receive water from ground-water inflow and from precipitation directly on the lake surface. Water is lost from these lakes by evaporation from the surface, ground-water outflow, and, for spring lakes, surface-water outlets. The percentage of lake water from precipitation, ground water, or streamflow varies even for lakes of similar hydrologic type. Therefore, intensive site-specific studies would be needed to characterize accurately the water and chemical budgets for a specific lake.

\section{Water Quality}

Thirty-four water samples were collected from 21 lakes in June and August 1982 and 1983 to determine lake-water quality, establish a data base for use in future studies, and to identify lakes that may be susceptible to acid precipitation. High concentrations of nutrients in lake water and the susceptibility of lake water to the effects of acid precipitation are factors that can degrade the quality of the lake fishery.

\section{Sampling Methods}

Samples were collected at a depth of $3 \mathrm{ft}$ below the water surface with a Kemmerer sampler. One sampling site was selected for each lake, and two or three sites were selected for larger (greater than 1,000 acres) lakes. Sampling sites were located at the deepest part(s) of each lake. All samples were collected and preserved according to USGS standard practices (U.S. Department of the Interior, 1977) and were 
Table 5. Hydrologic lake types and lake areas, Lac du Flambeau Indian Reservation, Wisconsin

Lake name

Area

(acres)

\section{Drainage Lakes}

Big Crooked Lake

Crawling Stone Lake

682

Flambeau Lake

1,466

Fence Lake

1,176

Haskell Lake

3,555

97

Lower Sugarbush Lake

Long Interlaken Lake

368

Middle Sugarbush Lake

269

North Placid Twin Lake

32

Pokegama Lake

1,052

Sunfish Lake 55

Upper Sugarbush Lake 162

Wild Rice Lake

379

White Sand Lake

1,229

West Ellerson Lake

80

Total

10,784

Spring Lakes

Bolton Lake

Gunlock Lake

Little Sugarbush Lake

Little Sand Lake

Signal Lake

58

Whitefish Lake

$\underline{205}$

Total

801 
Table 5. Hydrologic lake types and lake areas, Lac du Flambeau Indian Reservation, Wisconsin-Continued

\begin{tabular}{|c|c|}
\hline Lake name & $\begin{array}{c}\text { Area } \\
\text { (acres) }\end{array}$ \\
\hline \multicolumn{2}{|c|}{ Seepage Lakes } \\
\hline Bill's Lake & 70 \\
\hline Broken Bow Lake & 134 \\
\hline Bobidosh Lake & 47 \\
\hline Elsie Lake & 46 \\
\hline Gene Lake & 28 \\
\hline Headflyer Lake & 21 \\
\hline Ike Walton Lake & 1,424 \\
\hline Jerms Lake & 72 \\
\hline Little Trout Lake & 978 \\
\hline Moss Lake & 196 \\
\hline Mitten Lake & 140 \\
\hline Minette Lake & 90 \\
\hline Moving Cloud Lake & 16 \\
\hline Muskesin Lake & 115 \\
\hline Plummer Lake & 211 \\
\hline Poupart Lake & 49 \\
\hline Ross Allen Lake & 66 \\
\hline Raven Lake & 40 \\
\hline Statenaker Lake & 210 \\
\hline South Placid Twin Lake & 35 \\
\hline Stearns Lake & 217 \\
\hline Tippecanoe Lake & 155 \\
\hline Tank Lake & 13 \\
\hline Toulish Lake & 79 \\
\hline Warrior Lake & 25 \\
\hline Wishow Lake & 73 \\
\hline Wyandock Lake & 88 \\
\hline Zee Lake & 25 \\
\hline Total & 4,663 \\
\hline
\end{tabular}


analyzed at the USGS National Water-Quality Laboratory in Denver, Colo.

Water samples were analyzed for common chemical constituents, nutrients, and some trace metals to determine water quality. Analyses specifically included various forms of nitrogen and phosphorus, the primary nutrients needed for the growth of algae and lake weeds. Lake-water samples were also analyzed for alkalinity and $\mathrm{pH}$. Alkalinity represents the ability of the lake water to neutralize acid and withstand the effects of acid precipitation.

Vertical-depth profiles of water temperature, dissolved oxygen, $\mathrm{pH}$, and specific conductance also were obtained to show the distribution of these water-quality characteristics in selected lakes on the reservation. Data for these profiles were collected by use of a four-parameter water-quality meter lowered from a stationary boat.

\section{General Quality}

A summary of the major dissolved constituents and other chemical and physical properties of lakes on the reservation is given in table 6. Concentrations of the nutrients nitrogen and phosphorus also are included in table 6. Data from 34 water-quality analyses for 21 lakes are listed in table 7 .

A comparison of data in tables 6 and 2, especially dissolved-solids concentrations, shows that lake water is relatively dilute (low in dissolved minerals) compared to ground water on the reservation. The median concentration of dissolved solids in all ground-water samples was $86 \mathrm{mg} / \mathrm{L}$, compared with the median of $50 \mathrm{mg} / \mathrm{L}$ for all lake-water samples. Bicarbonate (reflected in the alkalinity values), calcium, and magnesium are the major dissolved constituents in lake water and ground water underlying the reservation; however, the concentrations in lakewater samples are only about half the concentrations in ground-water samples (tables 6 and 2).

In addition to the summary of all lake-water analyses, water-quality data are grouped by hydrologic lake type (discussed in previous section) in table 6. Median concentrations of dissolved minerals are similar for drainage and spring lakes; however, seepage lakes are far more dilute. The median concentration of dissolved solids in seepage lakes was only $26 \mathrm{mg} / \mathrm{L}$ compared with $54 \mathrm{mg} / \mathrm{L}$ in drainage lakes and $62 \mathrm{mg} / \mathrm{L}$ in spring lakes. The difference is even more pronounced when alkalinity and hardness are compared by lake type. The median alkalinity in seepage lakes was only $6 \mathrm{mg} / \mathrm{L}$ compared to $38 \mathrm{mg} / \mathrm{L}$ in drainage lakes and $40 \mathrm{mg} / \mathrm{L}$ in spring lakes. Seepage-lake water is also very soft with a median hardness of only $8 \mathrm{mg} / \mathrm{L}$ as compared to a median hardness of $39 \mathrm{mg} / \mathrm{L}$ for drainage lakes and $41 \mathrm{mg} / \mathrm{L}$ for spring lakes. These differences indicate that, compared with the other lake types, seepage lakes on the reservation receive a much higher percentage of water from direct precipitation, which is very low in concentrations of those dissolved minerals that contribute to hardness, alkalinity, and overall dissolved-solids concentrations.

The distribution of dissolved-oxygen concentration, water temperature, and to a lesser extent, the $\mathrm{pH}$ and specific conductance (an indicator of dissolved-solids concentration) in the lake-water column affects the health and distribution of fish and plant life in the lake. Depth profiles of water temperature, dissolved oxygen, $\mathrm{pH}$, and specific conductance were plotted for a total of 22 reservation lakes in 1982 and 1983. Several of these lakes were profiled on two or more dates and at two or more locations in the lake. The results of these profiles are shown in figure 3. Most of the lakes that are deeper than $25 \mathrm{ft}$ are thermally stratified during the summer. There is a distinct change in temperature and dissolved-oxygen concentrations at a given depth in a stratified lake.

Three water-temperature layers form in stratified lakes. These are the epilimnion, which is the uppermost layer where temperature is fairly uniform and warm; the metalimnion (or thermocline), which is the middle layer where water temperature decreases rapidly with depth; and the hypolimnion, which is the lowermost layer where water is coldest and unaffected by wind action. Dissolved-oxygen concentrations usually decreased rapidly in the hypolimnion. This decrease results when warm, oxygenated, upper water is unable to mix with the lower, cooler water. This effectively restricts the supply of dissolved oxygen to this lower hypolimnion layer. The dissolved-oxygen concentration in the hypolimnion can be further reduced by decaying 


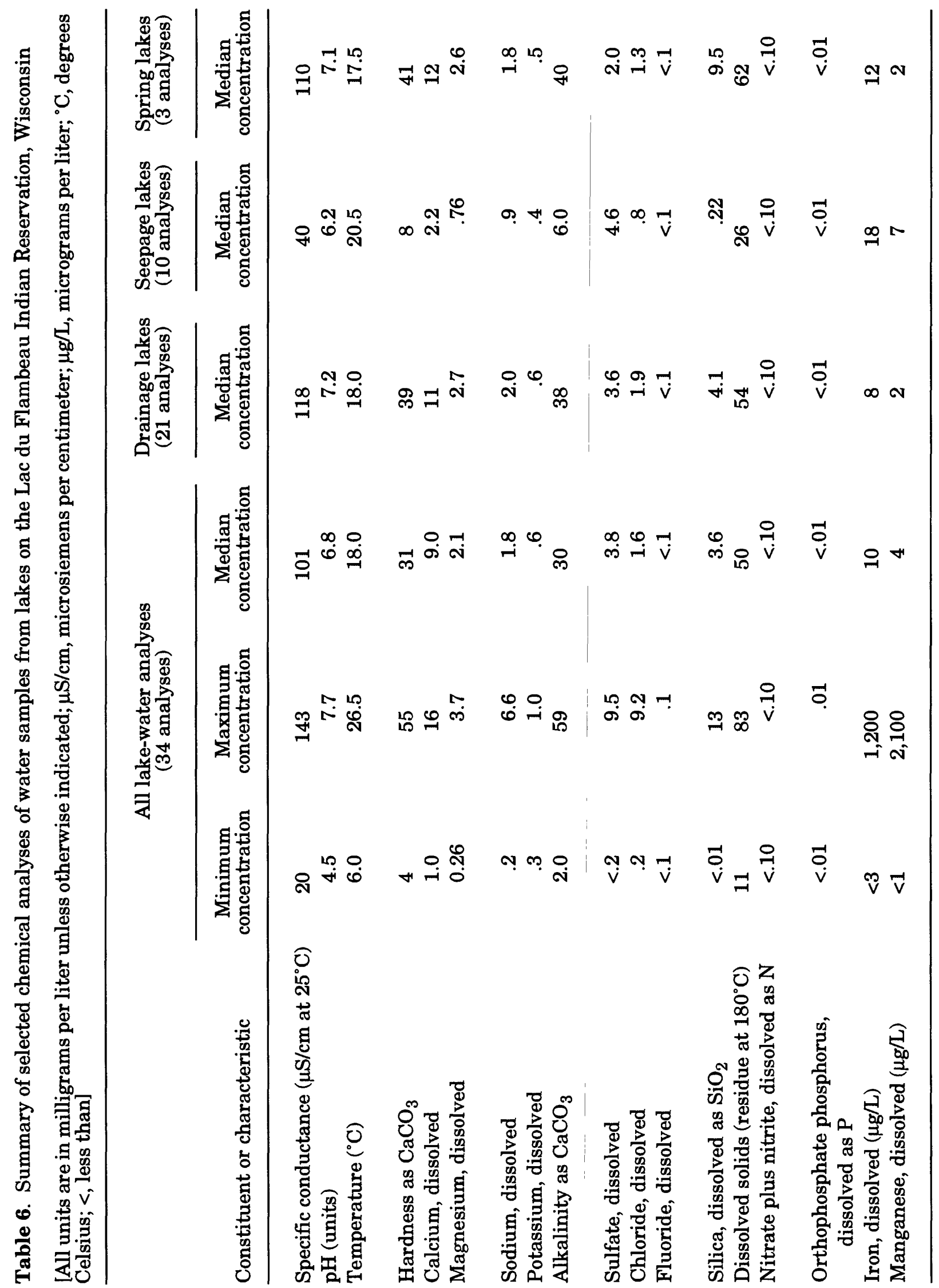




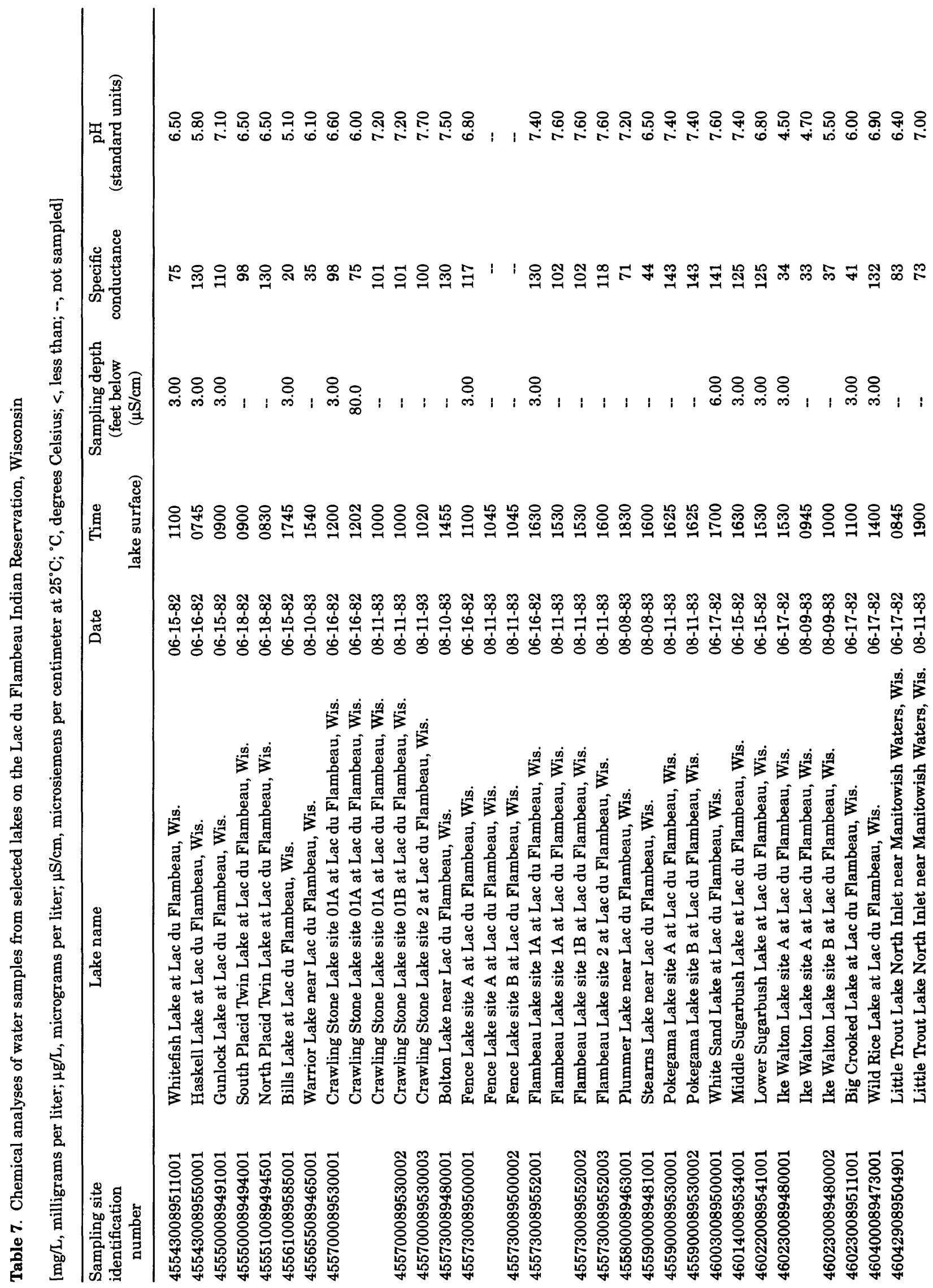




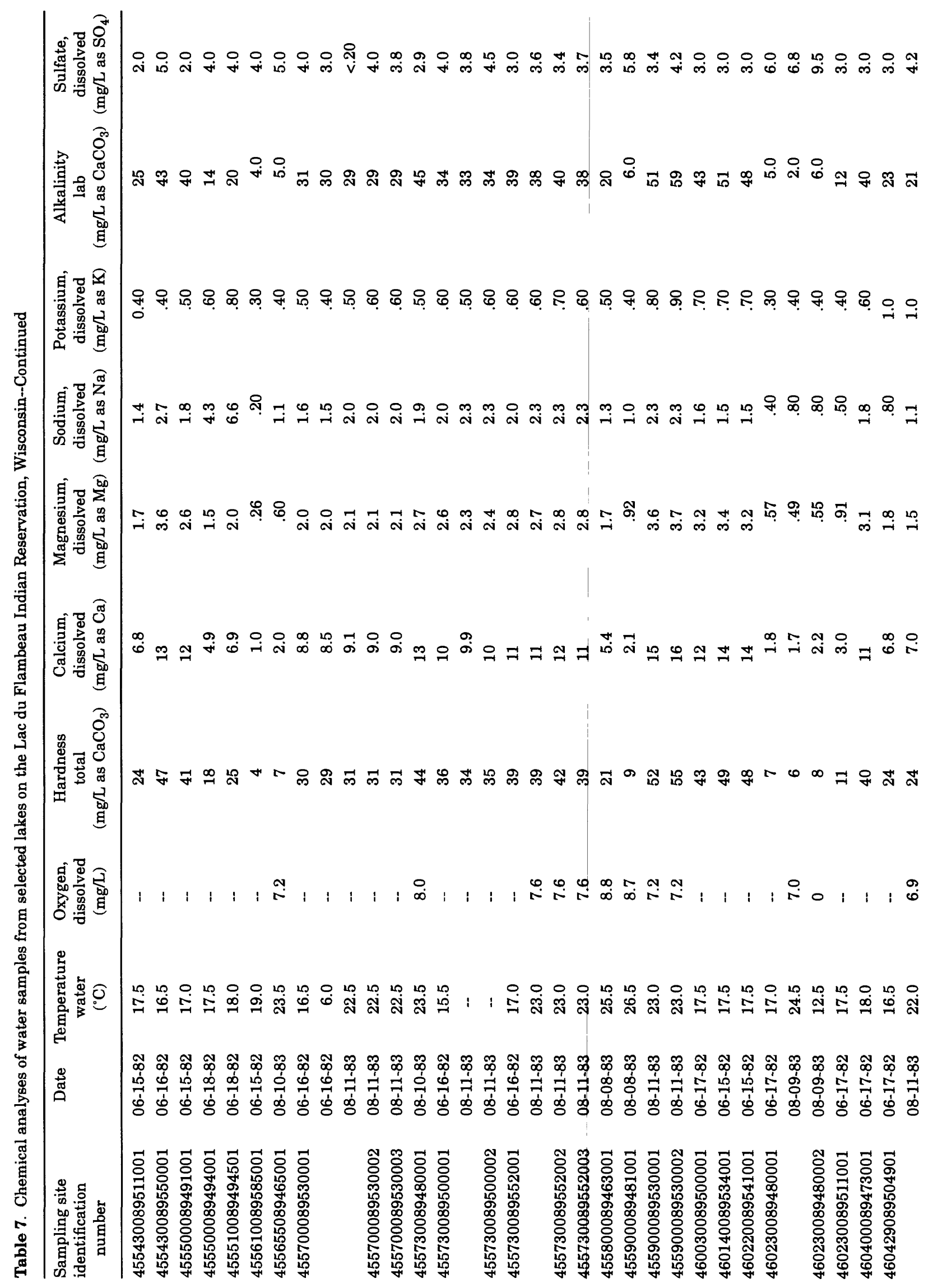




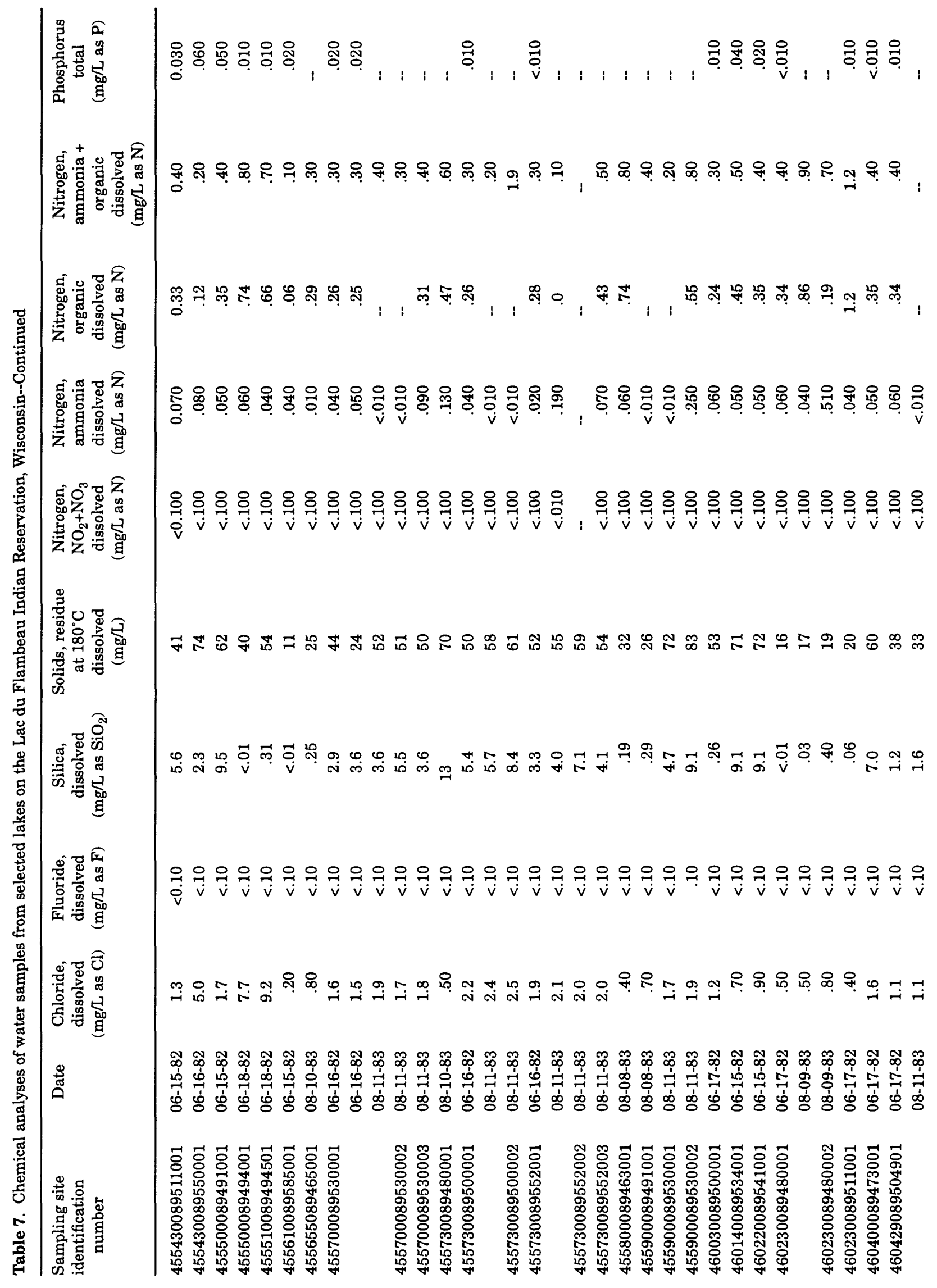




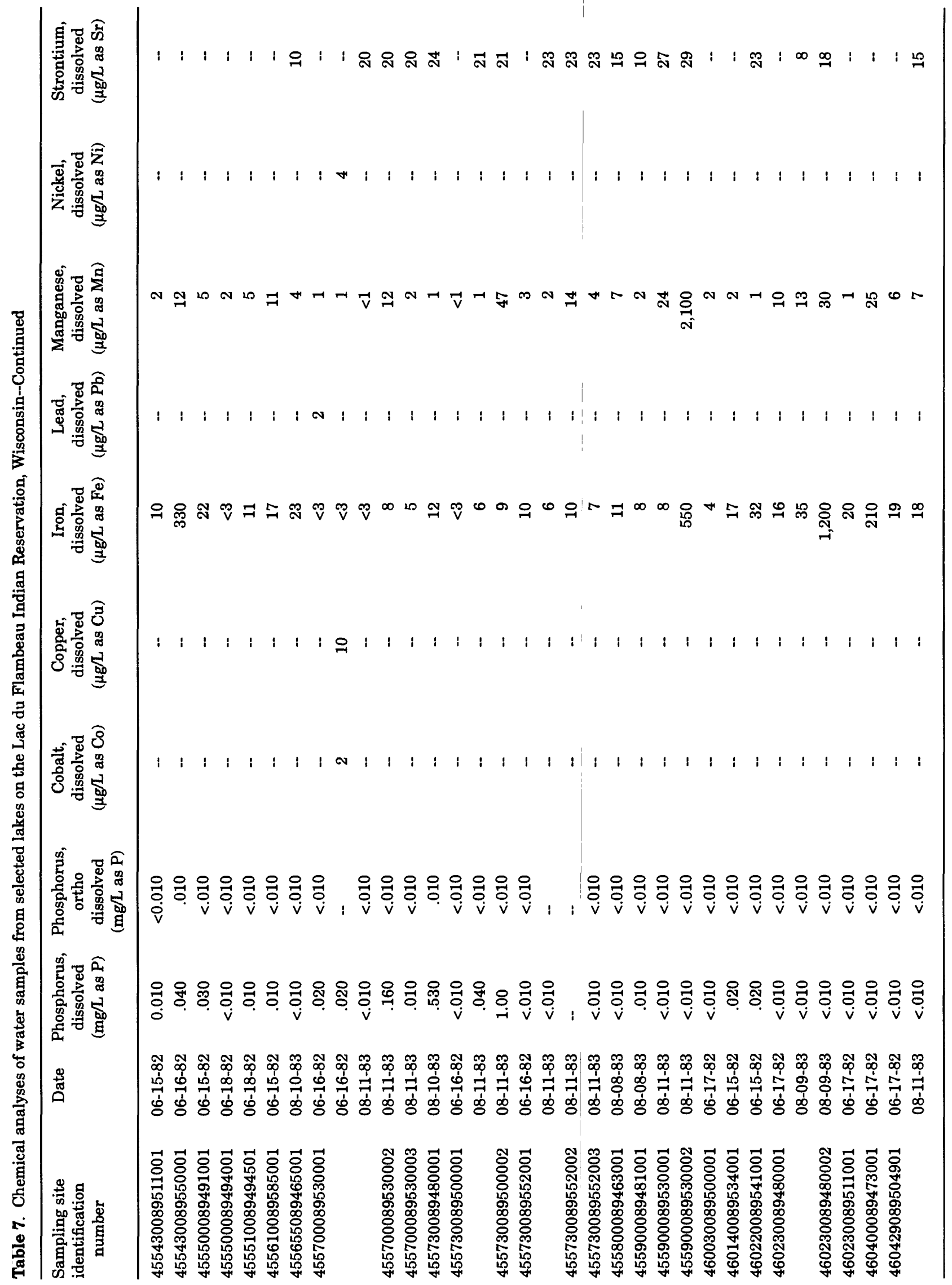




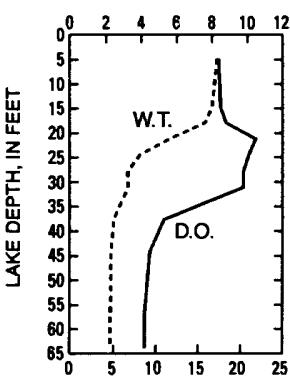

DISSOLVED OXYGEN (DO), IN MILUGRAMS PER LITER
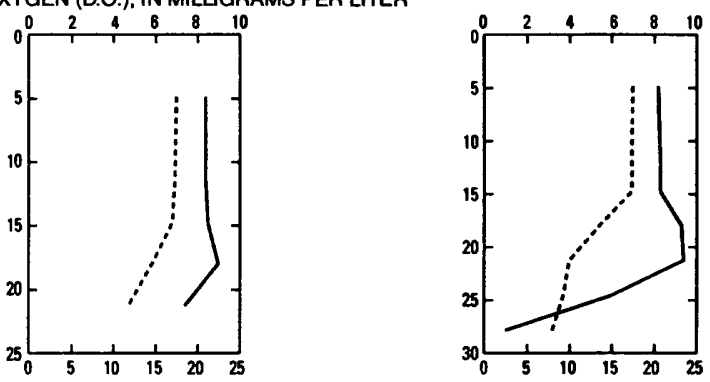

WATER TEMPERATURE (W.T), IN DEGREES CELSIUS
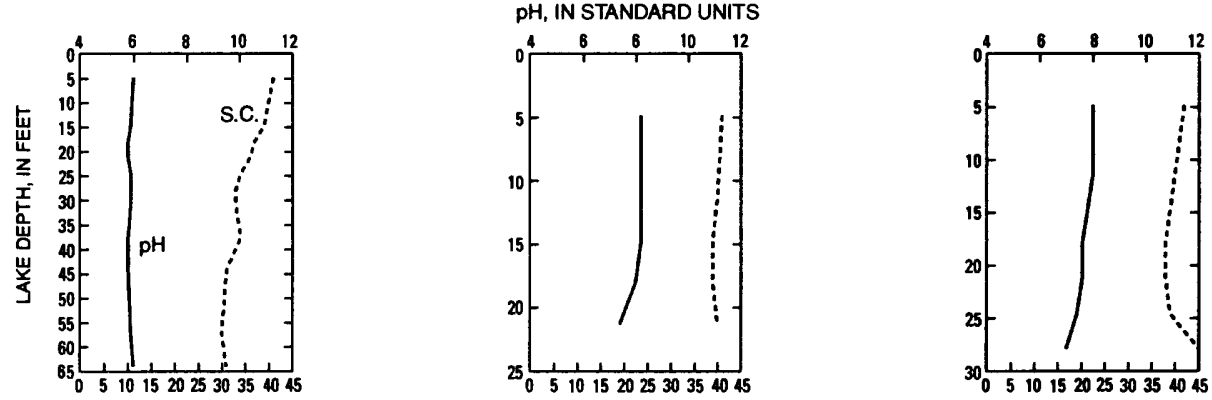

SPECIFIC CONDUCTANCE (S.C.), IN MICROSIEMENS PER CENTIMETER AT 25 DEGREES CELSIUS

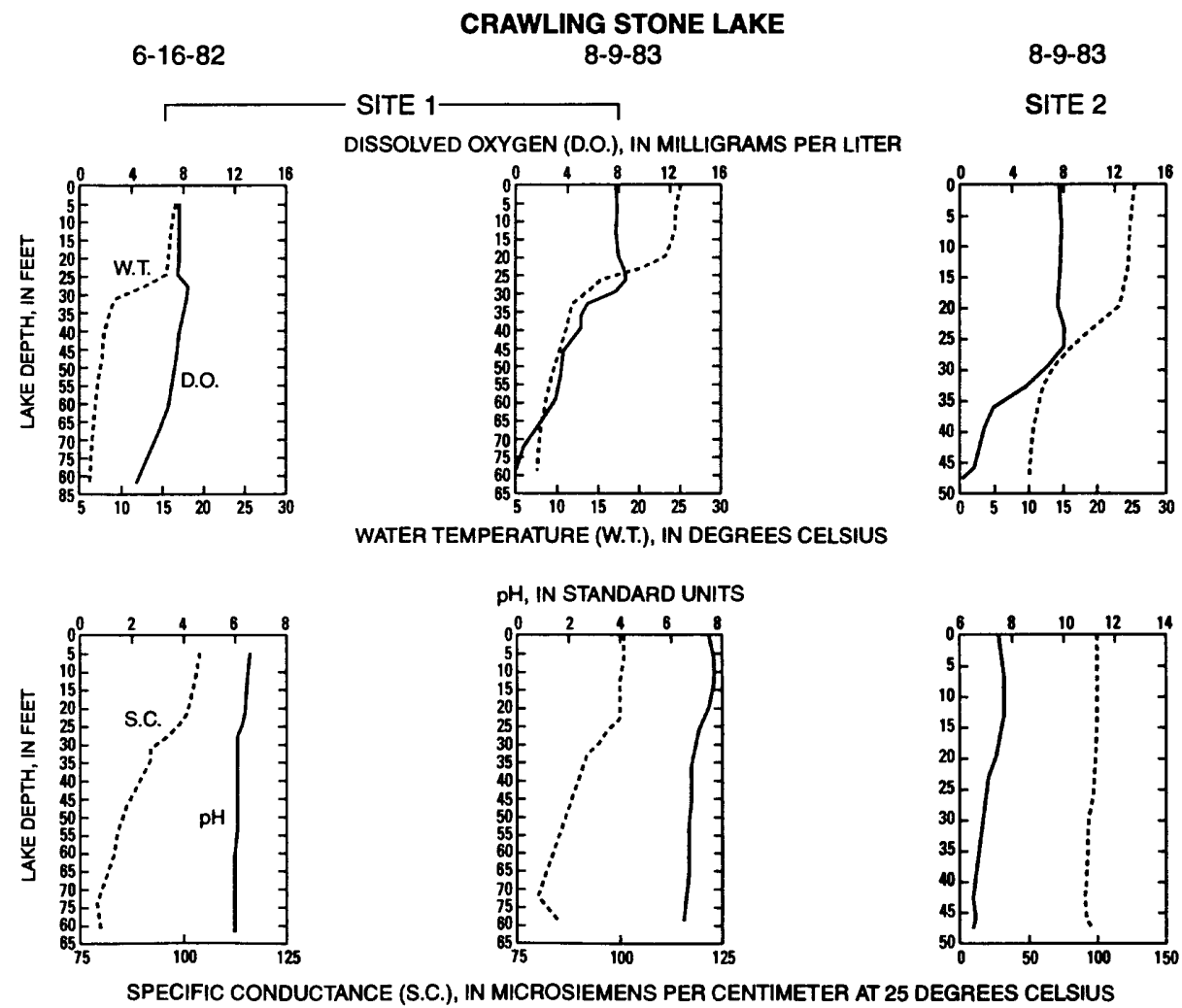

Figure 3. Depth profiles of water temperature, dissolved-oxygen concentration, $\mathrm{pH}$, and specific conductance for 22 lakes on the Lac du Flambeau Indian Reservation, Wisconsin. 

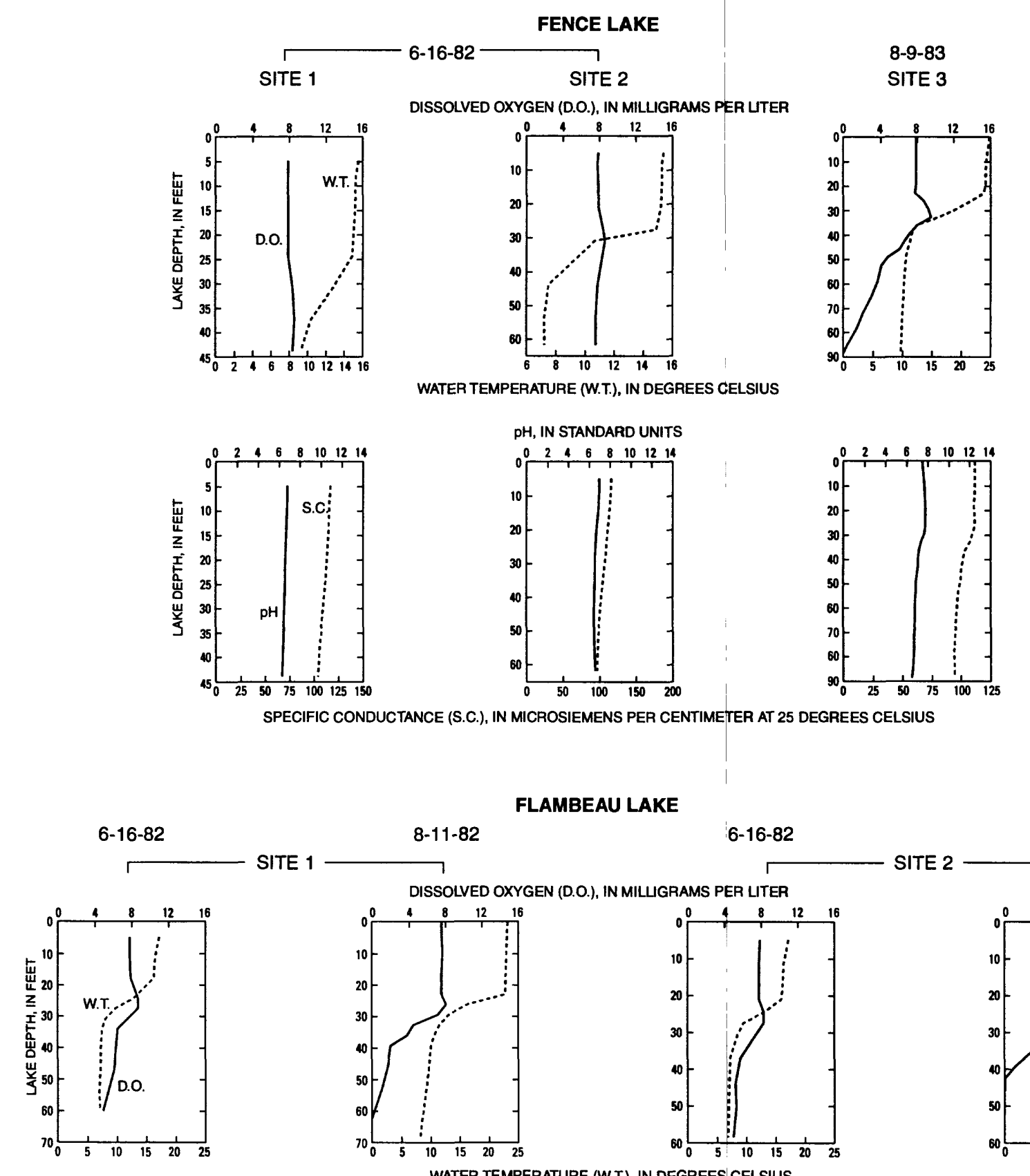

SITE 1

8-11-82

FLAMBEAU LAKE

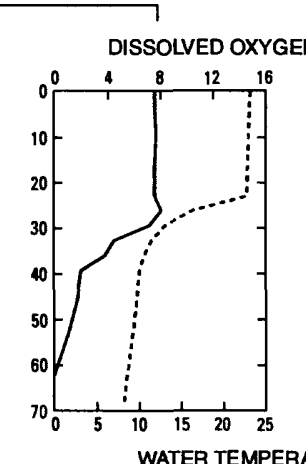

6-16-82

$8-11-83$
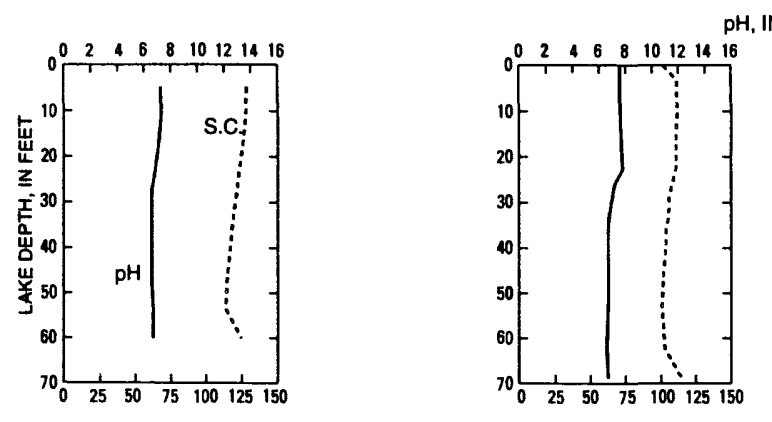

PH, IN STANDARD UNITS

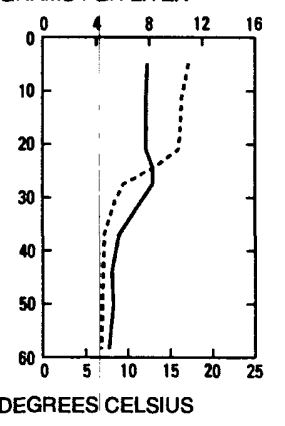
SITE 2

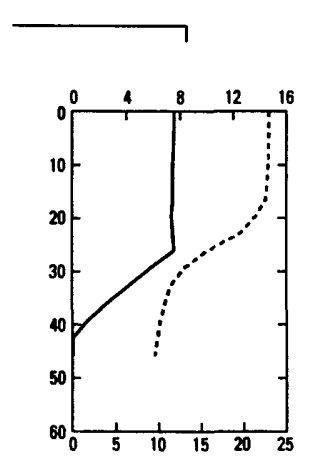

SPECIFIC CONDUCTANCE (S.C.), IN MICROSIEMENS PER CENTIMETER AT 25 DEGREES CELSIUS

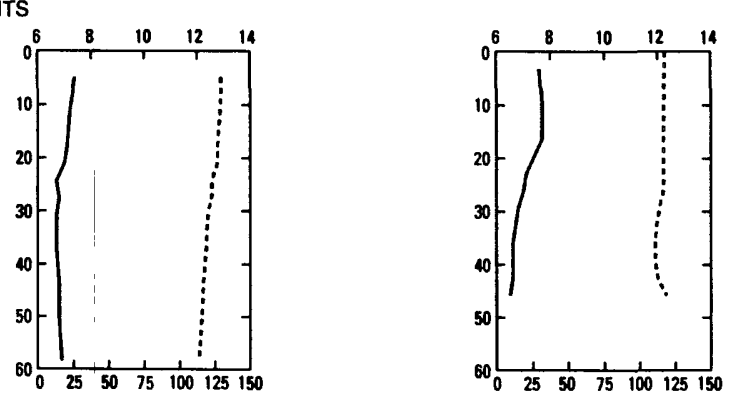

Figure 3. Depth profiles of water temperature, dissolved-oxygen concentration, $\mathrm{pH}$, and specific conductance for 22 lakes on the Lac du Flambeau Indian Reservation, Wisconsin--Continued. 


\section{IKE WALTON LAKE}

6-17-82

8-9-83

8-9-83

SITE 1

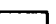

DISSOLVED OXYGEN (D.O.), IN MILLIGRAMS PER LITER
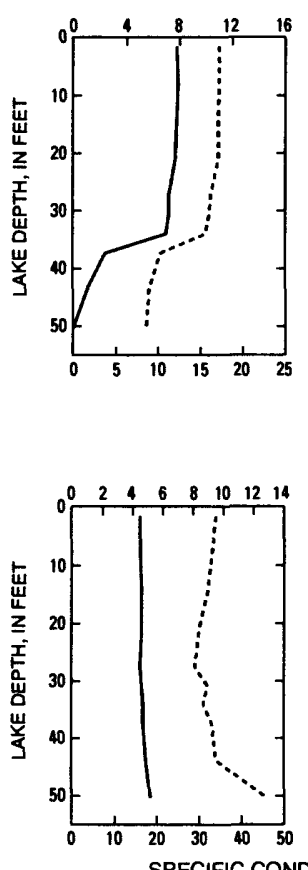

SPECIFIC CONDUCTANCE (SC.), IN MICROSIEMENS PER CENTIMETER AT 25 DEGREES CELSIUS $\begin{array}{lllll}10 & 10 & 20 & 30 & 40\end{array}$

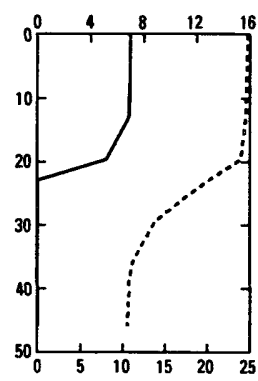

WATER TEMPERATURE (W.T.), IN DEGREES CELSIUS

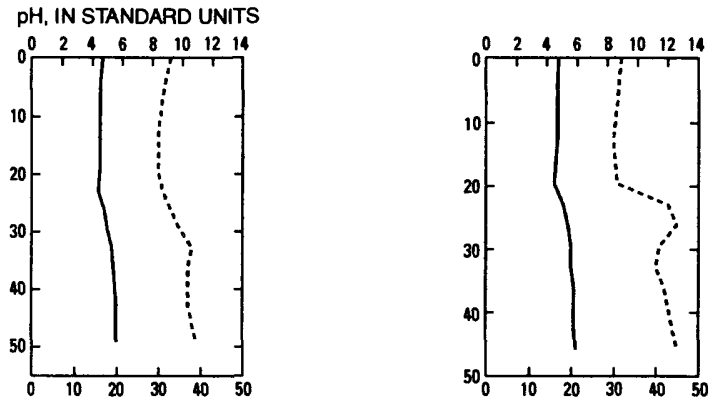

LITTLE TROUT LAKE

POKEgAMA LAKE

6-16-82

8-11-83

6-16-82

SITE 2

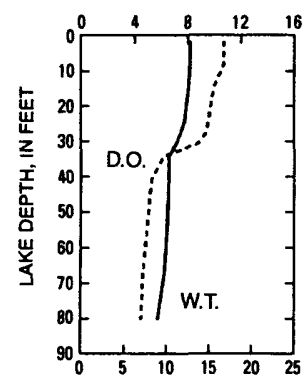

DISSOLVED OXYGEN (D.O.), IN MILLIGRAMS PER LTER
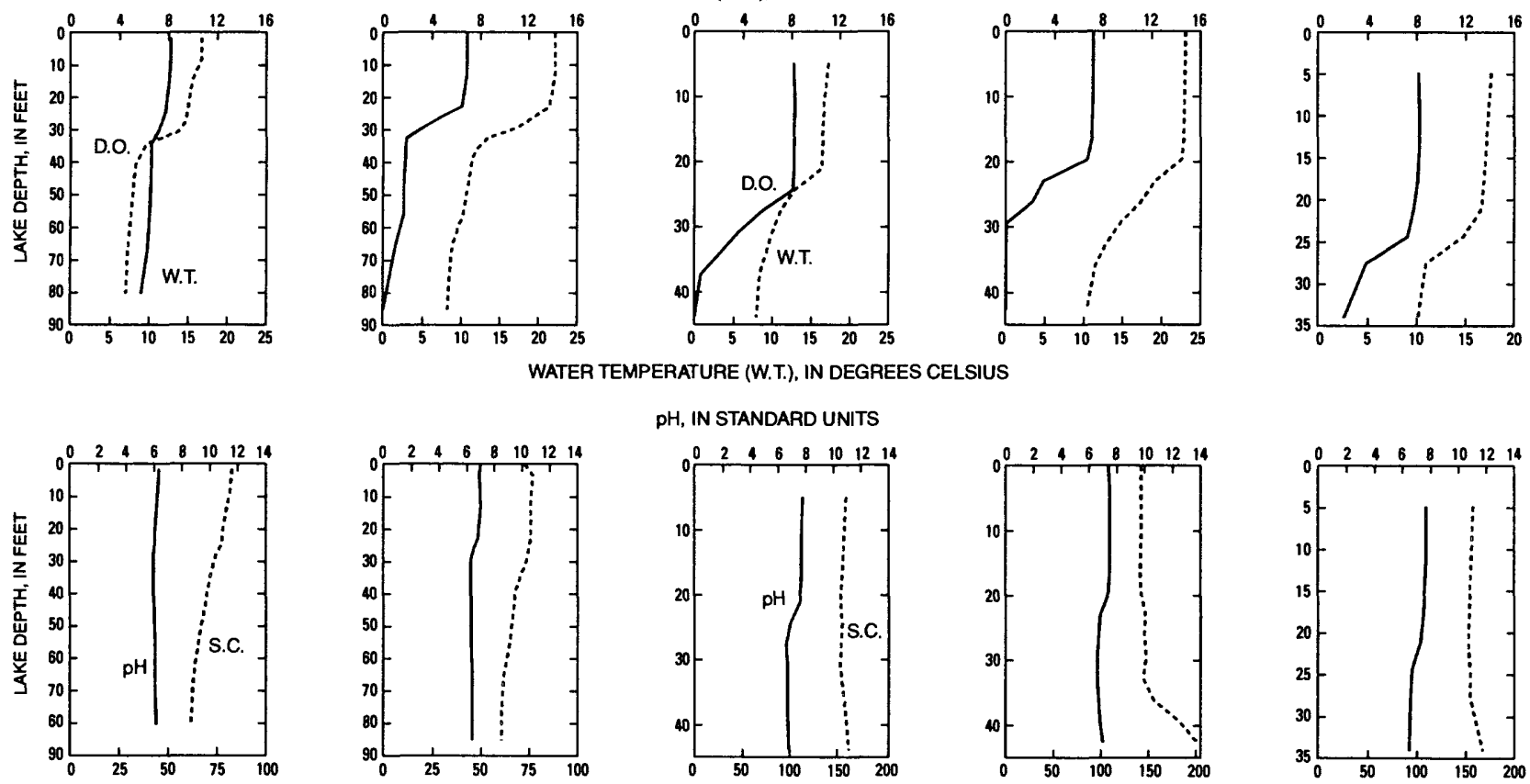

PH, IN STANDARD UNITS
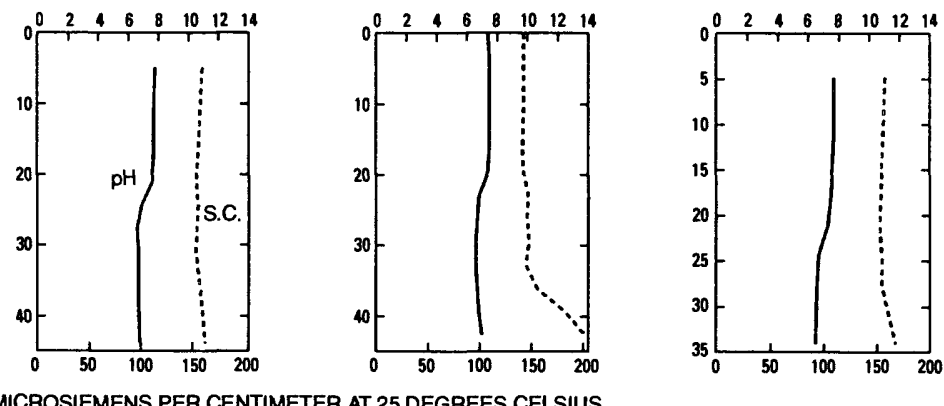

Figure 3. Depth profiles of water temperature, dissolved-oxygen concentration, $\mathrm{pH}$, and specific conductance for 22 lakes on the Lac du Flambeau Indian Reservation, Wisconsin--Continued. 
BILLS LAKE

6-15-82

SITE 1
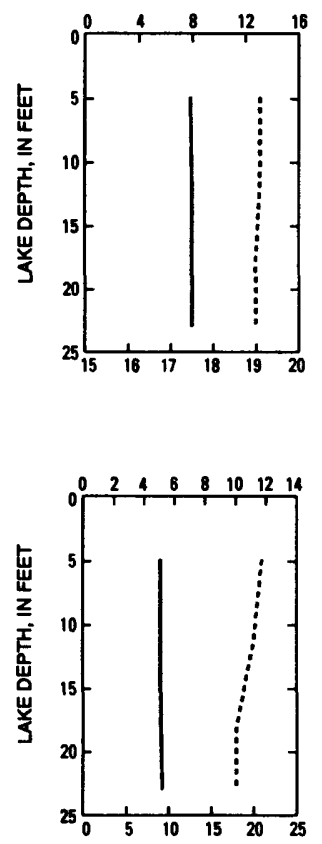

LITLE SUGARBUSH

LAKE

6-15-82

SITE 1
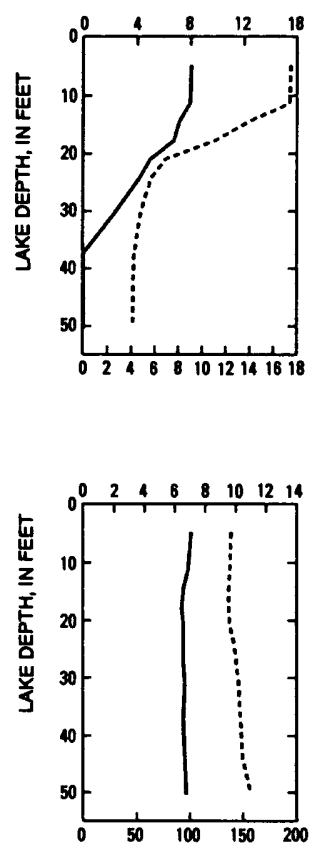

BOLTON LAKE

8-10-82

SITE 1

DISSOLVED OXYGEN (D.O.), IN MILLIGRAMS PER LTER
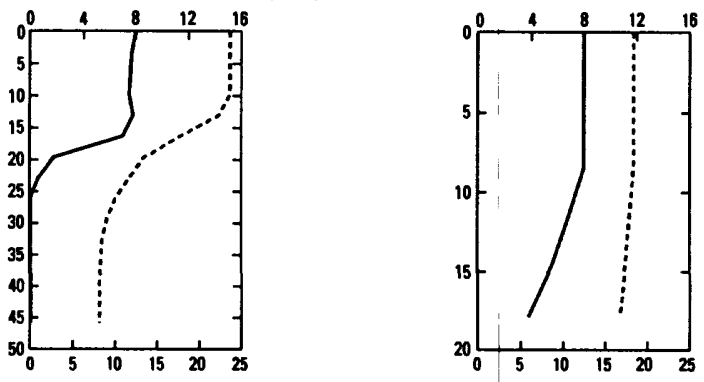

WATER TEMPERATURE (W.T.), IN DEGREES CELSIUS

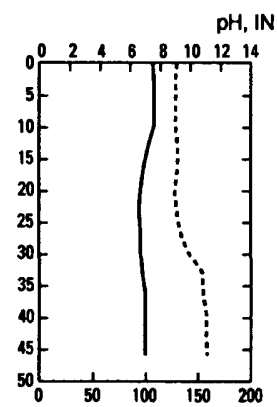

PH, IN STANDARD UNITS

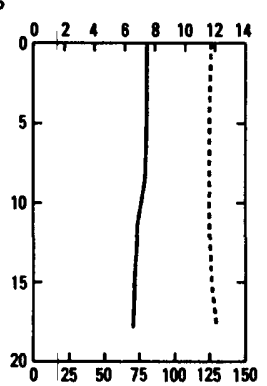

SPECIFIC CONDUCTANCE (S.C.), IN MICROSIEMENS PER CENTIMETER AT 25 DEGREES CELSIUS

MIDDLE SUGARBUSH

LAKE

6-15-82

SITE 1

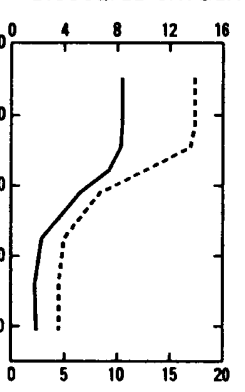

WATER TEMPERATURE (W.T.), IN DEGREES CELSIUS

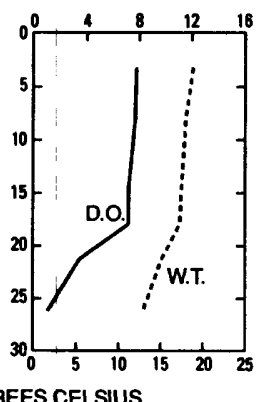

PH, IN STANDARD UNITS

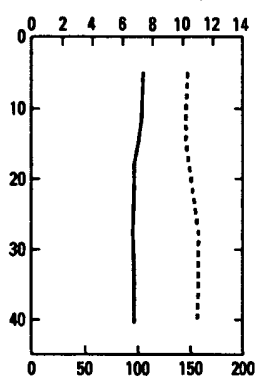

MOSS LAKE

6-16-82

SITE 1

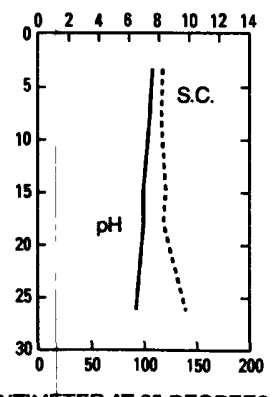

HASKELL LAKE

6-16-82

SITE 1
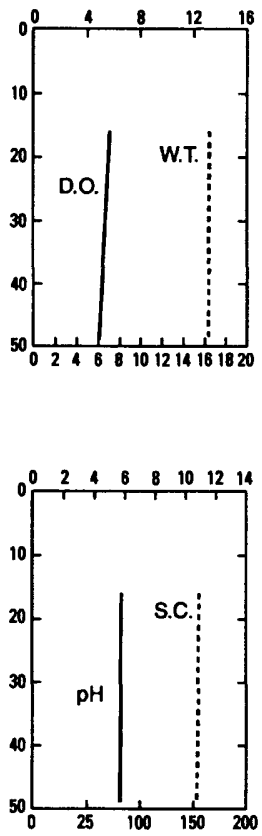

NORTH PLACID LAKE

6-18-82

SITE 1
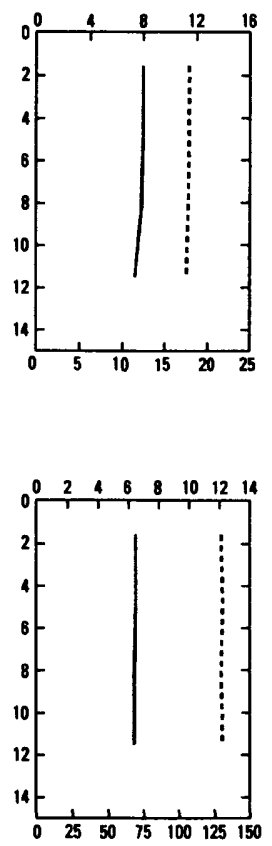

SPECIFIC CONDUCTANCE (S.C.), IN MICROSIEMENS PER CENTIMETER AT 25 DEGREES CELSIUS

Figure 3. Depth profiles of water temperature, dissolved-oxygen concentration, $\mathrm{pH}$, and specific conductance for 22 lakes on the Lac du Flambeau Indian Reservation, Wisconsin--Continued. 


\section{PLUMMER LAKE}

8-8-83

SITE 1
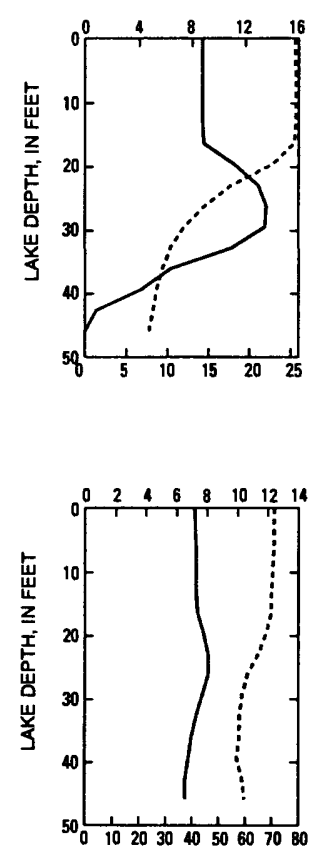

WHITEFISH LAKE

6-15-82

SITE 1
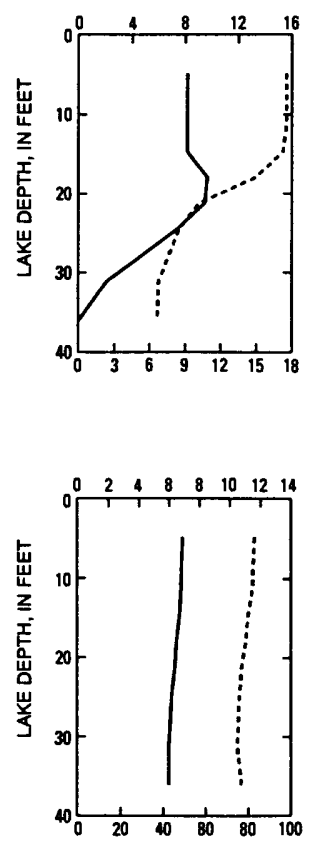

SOUTH PLACID LAKE

6-18-82

SITE 1

DISSOLVED OXYGEN (D.O.), IN MILIGRAMS PER LITER

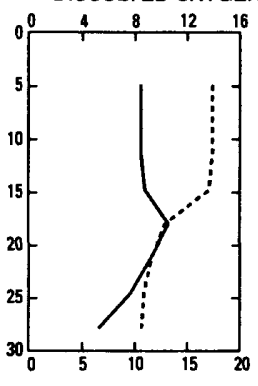

WATER TEMPERATURE (W.T.), IN DEGREES CELSIUS

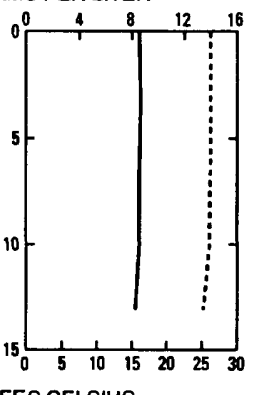

$\mathrm{PH}$, IN STANDARD UNITS
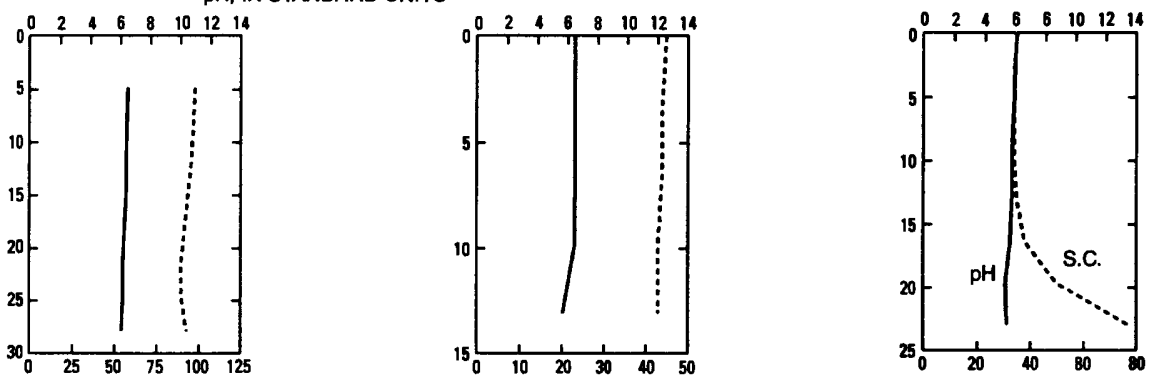

WARRIOR LAKE

8-10-83

SITE 1

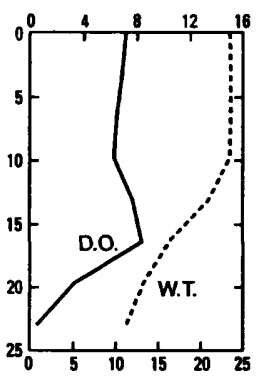

SPECIFIC CONDUCTANCE (S.C.), IN MICROSIEMENS PER CENTIMETER AT 25 DEGREES CELSIUS

DISSOLVED OXYGEN (D.O.), IN MILLIGRAMS PER LITER
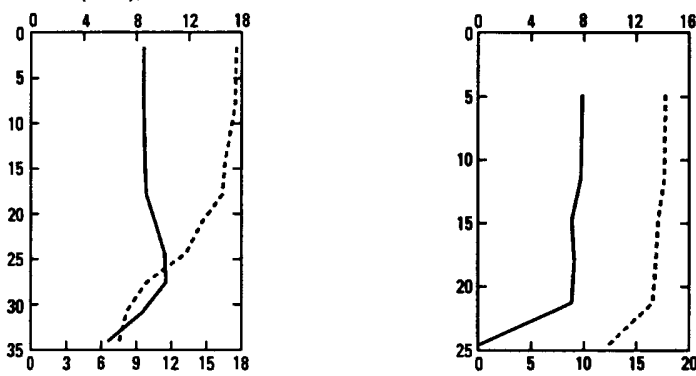

WATER TEMPERATURE (W.T.), IN DEGREES CELSIUS
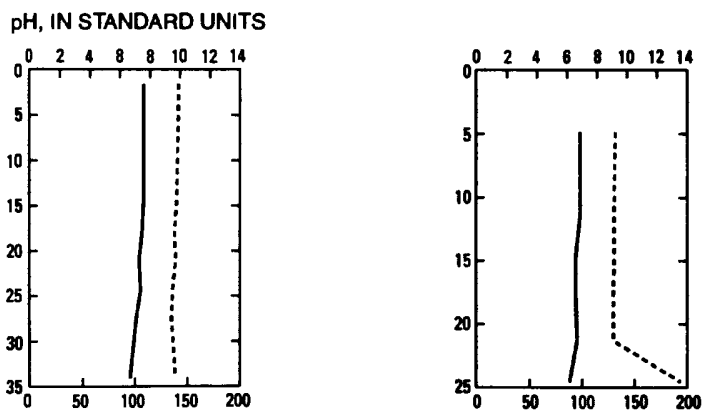

SPECIFIC CONDUCTANCE (S.C.), IN MICROSIEMENS PER CENTIMETER AT 25 DEGREES CELSIUS

Figure 3. Depth profiles of water temperature, dissolved-oxygen concentration, $\mathrm{pH}$, and specific conductance for 22 lakes on the Lac du Flambeau Indian Reservation, Wisconsin--Continued. 
of organic material that falls to the bottom of the lake.

\section{Nutrients and Pesticides}

Water from reservation lakes was also analyzed to determine the concentrations of various forms of nitrogen and phosphorus. These chemical constituents, commonly known as nutrients, control the growth of lake weeds and algae. Concentrations of the forms of nitrogen available as nutrients are shown in tables 6 and 7. Phosphorus concentrations were relatively high in many of the lakes (table 7). Lakes are often classified as to their potential productivity of nuisance algae and plants by the concentrations of total phosphorus in their waters. The Wisconsin Department of Natural Resources (1981) classifies lakes as eutrophic (highly enriched) when the total-phosphorus concentration is greater than $0.02 \mathrm{mg} / \mathrm{L}$. This is a general classification; to be able to classify a lake definitively, more detailed, site-specific work would need to be done. Total-phosphorus concentrations of $0.02 \mathrm{mg} / \mathrm{L}$ or higher were measured in the following lakes on the reservation:

$\begin{array}{ll}\text { Bill's Lake } & \text { Lower Sugarbush Lake } \\ \text { Crawling Stone Lake } & \begin{array}{l}\text { Middle Sugarbush Lake } \\ \text { Gunlock Lake }\end{array} \\ \text { Haskell Lake } & \end{array}$

Because of cranberry operations on the margins of Little Trout Lake in the northern part of the reservation, bottom material samples were collected and analyzed for the following pesticide residues:

\author{
Aldrin \\ Chlordane \\ DDD (Dichlorodiphenyltrichloroethane) \\ DDE (Dichlorodiphenyldichloroethane) \\ DDT (Dichlorodiphenyldichloroethylene) \\ Dieldrin \\ Endolsulfan \\ Endrin \\ Heptachlor \\ Heptachlor expoxide \\ Lindane \\ Methoxychlor \\ Mirex \\ Toxaphene \\ Perthane \\ Parathion
}

All concentrations were below the analytical detection limits of 0.1 or $1.0 \mu \mathrm{g} / \mathrm{kg}$. Subsequent sampling of the water column for pesticides by the Lac du Flambeau Fish and Game Department yielded similar results (Larry Wawronowicz, Lac du Flambeau Fish and Game Department, written commun., 1988).

\section{Acid Sensitivity}

The rocks, glacial materials, and soils underlying the Lac du Flambeau Indian Reservation and much of northern Wisconsin contain few carbonate minerals. This results in a lack of dissolved-carbonate minerals in lake, stream, and ground water in this area. Dissolvedcarbonate minerals provide bicarbonate ions that increase the alkalinity of the water. Alkalinity, as discussed earlier, is the measure of the ability of the water to neutralize acid. Lakes with relatively low alkalinity may not have the buffering capacity to neutralize a lowering of $\mathrm{pH}$ (acidification) from long-term acid precipitation or from acid loading from melting snow if the snow has a low $\mathrm{pH}$.

A recent categorization for seepage lakes (Garrison and others, 1987) classifies lakes with an alkalinity less than $2 \mathrm{mg} / \mathrm{L}$ as susceptible to damage from acid precipitation, and those with an alkalinity greater than $2 \mathrm{mg} / \mathrm{L}$ as not susceptible to acid precipitation. According to this classification, the only lake sampled on the reservation that seems to be susceptible to damage by acid precipitation is Ike Walton Lake (a seepage lake). One set of samples from the lake had an alkalinity of about $2 \mathrm{mg} / \mathrm{L}$; however, other samples from the same lake had alkalinities of 5 and $6 \mathrm{mg} / \mathrm{L}$. Three samples from this lake also had field $\mathrm{pH}$ values of $4.5,4.7$, and $5.5 \mathrm{pH}$ units-considerably lower than any of the other lakes on the reservation. Although Ike Walton Lake is the only lake that seems to be sensitive to acid precipitation according to Garrison's classification, several other lakes had a $\mathrm{pH}$ below 7.0 units and alkalinities below $10 \mathrm{mg} / \mathrm{L}$ (table 7). The $\mathrm{pH}$ and alkalinity of water in these lakes may be considerably lower during periods of snowmelt thus increasing their susceptibility to damage by acid precipitation. 


\section{SUMMARY}

A study completed by the U.S. Geological Survey, in cooperation with the Lac du Flambeau Indian Reservation, characterized the groundwater hydrology and lake-water quality within the reservation. Data were collected from 1981 to 1986. The Lac du Flambeau Indian Reservation obtains drinking water exclusively from the glacial sand and gravel aquifer that overlies Precambrian bedrock. Ground water is in abundant supply and readily available on the reservation where the saturated thickness of the aquifer ranges from about 60 to more than $220 \mathrm{ft}$. Estimated horizontal hydraulic conductivities of the aquifer range from about 0.7 to $54 \mathrm{ft} / \mathrm{d}$; a 48-hour aquifer test of a gravel-packed-well finished in coarse sand and gravel gave a site-specific hydraulic conductivity of $950 \mathrm{ft} / \mathrm{d}$.

The surface-water hydrology of the reservation is dominated by lakes. Seepage lakes, spring lakes, and drainage lakes are all present on the reservation.

Calcium, magnesium, bicarbonate, and to a lesser extent, chloride and sulfate are the major-dissolved ions in ground and surface water underlying the reservation. Concentrations of these chemical constituents in lake water are about half the concentrations in ground water.

Only one constituent (cadmium) in one sample of ground water exceeded the Wisconsin drinking-water standards $(10 \mu \mathrm{g} / \mathrm{L})$. Ground water on the reservation can be classified from soft to hard. Hardness of water samples from 15 of 25 wells was below $60 \mathrm{mg} / \mathrm{L}$ (as $\mathrm{CaCO}_{3}$ ), thus classifying them as soft.

In some of the lakes, concentrations of total phosphorus were found that would classify these lakes as eutrophic; however, this should not be considered a definitive classification because of the limited amount of data collected during this study. According to the classification scheme used for acid sensitivity, only Ike Walton Lake is potentially susceptible to damage by acid precipitation.

\section{SELECTED REFERENCES}

Attig, J.W., 1985, Pleistocene geology of Vilas County, Wisconsin: Wisconsin Geological and Natural History Survey Information Circular $50,32 \mathrm{p}$.
Bouwer, Herman, and Rice, R.C., 1976, A slug test for determining hydraulic conductivity of unconfined aquifers with completely or partially penetrating wells: Water Resources Research, v. 12 , no. 3 , p. 423-428.

Durfor, C.N., and Becker, E., 1964, Public water supplies of the 100 largest cities in the United States, 1962: U.S. Geological Survey Water-Supply Paper 1812, 364 p.

Freeze, R.A., and Cherry, J.A., 1979, Groundwater: Englewood Cliffs, N.J., Prentice-Hall, Inc., $604 \mathrm{p}$.

Garrison, P.J., and others, 1987, Application of the ILWAS model to the northern great lake states, in Lake and Reservoir Management, vol. 3, p. 356-364.

Hem, J.D., 1985, Study and interpretation of the chemical characteristics of natural water (3d ed.): U.S. Geological Survey Water-Supply Paper 2254, 263 p.

Hole, F.D., 1976, Soils of Wisconsin: Madison, Wis., The University of Wisconsin Press, $223 \mathrm{p}$.

Kammerer, P.A., Jr., 1981, Ground-water- quality atlas of Wisconsin: Wisconsin Geological and Natural History Survey Information Circular $39,39 \mathrm{p}$.

Lurie, N.O., 1987, Wisconsin Indians: State Historical Society of Wisconsin, $66 \mathrm{p}$.

Mudrey, M.G., Jr., and others, 1982, Bedrock geologic map of Wisconsin: University of Wisconsin-Extension Geological and Natural History Survey, scale 1:1,000,000, 1 sheet.

U.S. Department of Interior, 1977, National handbook of recommended methods for water-data acquisition: U.S. Geological Survey, Office of Water-Data Coordination [variously paged].

U.S. Environmental Protection Agency, 1986, Quality criteria for water, 1986: Washington, D.C., Office of Water Regulations and Standards, EPA 440/5-86-001 [variously paged]. 
Wallin, Mark J.R.S., 1988, Environmental health profile of Lac du Flambeau Reservation: Lac du Flambeau, Wis., Chippewa Health Center, 8 p.

Wisconsin Department of Natural Resources, 1978, Wisconsin administrative code, chapter NR 109, Safe drinking water: Register, February 1978, No. 266, Environmental Protection.
1981, Wisconsin lakes: Wisconsin Department of Natural Resources, Bureau of Fish Management, Madison, Wis., p. 92.

Wisconsin Legislative Reference Bureau, 1986, State of Wisconsin Blue Book 1985-1986: Madison, Wis., Department of Administration, p. 986 . 